\title{
Reconnecting Eye to Brain
}

\author{
Michael C. Crair ${ }^{1 *}$ and $\mathbb{Q C A r o l ~ A . ~ M a s o n ~}^{2 *}$ \\ ${ }^{1}$ Departments of Neuroscience and Ophthalmology \& Visual Science, Yale University, New Haven, Connecticut 06520, and ${ }^{2}$ Departments of Pathology and \\ Cell Biology, Neuroscience, and Ophthalmology, Mortimer B. Zuckerman Mind Brain Behavior Institute, Columbia University, New York, New York 10032
}

\begin{abstract}
Although much is known about the regenerative capacity of retinal ganglion cells, very significant barriers remain in our ability to restore visual function following traumatic injury or disease-induced degeneration. Here we summarize our current understanding of the factors regulating axon guidance and target engagement in regenerating axons, and review the state of the field of neural regeneration, focusing on the visual system and highlighting studies using other model systems that can inform analysis of visual system regeneration. This overview is motivated by a Society for Neuroscience Satellite meeting, "Reconnecting Neurons in the Visual System," held in October 2015 sponsored by the National Eye Institute as part of their "Audacious Goals Initiative" and co-organized by Carol Mason (Columbia University) and Michael Crair (Yale University). The collective wisdom of the conference participants pointed to important gaps in our knowledge and barriers to progress in promoting the restoration of visual system function. This article is thus a summary of our existing understanding of visual system regeneration and provides a blueprint for future progress in the field.
\end{abstract}

Key words: axon; axon guidance; axon regeneration; eye; lateral geniculate nucleus; optic nerve; regeneration; retina; retinal ganglion cells; superior colliculus; traumatic brain injury; vision; visual cortex

\section{Introduction}

Following traumatic injury to the optic nerve, or as the result of blinding neurodegenerative conditions, such as glaucoma and optic neuropathies, retinal ganglion cells (RGCs) fail to regenerate their axons, resulting in permanent and irreversible blindness. Here, we will review the state of the field on RGC axon guidance and target engagement during development and regeneration, and on our current knowledge of regeneration mechanisms. We will further point out the challenges, and propose some opportunities for addressing gaps in our knowledge of mechanisms of regeneration, to implement regrowth and reconnection in the visual system. This review stems from a Satellite meeting held before the 2015 Society for Neuroscience, "Reconnecting Neurons in the Visual System" convened by the National Eye Institute as part of their Audacious Goals Initiative. The purpose of this meeting was to (1) review state-of-the art findings on RGC axon guidance and target engagement, and identify the range of approaches being used in the field; and (2) to provide a public forum to discuss ideas and approaches to reconnecting visual system neurons after injury or

\footnotetext{
Received June 16, 2016; revised Sept. 3, 2016; accepted Sept. 8, 2016.

This work was supported by the Family of William Ziegler, III and the National Eye Institute Grants EY015788 and EY023105 to M.C.C. and EY012736 and EY015290 to C.A.M. We thank Paul Sieving, Tom Greenwell, and Steve Becker of the National Eye Institute for convening the Satellite meeting from which this article emanated and the conference panelists and participants for their enthusiastic participation.

The authors declare no competing financial interests.

*M.C.C. and C.A.M. contributed equally to this work.

Correspondence should be addressed to either of the following: Dr. Michael C. Crair, Department of Neuroscience, 333 Cedar Street, SHM B301, Yale University School of Medicine, New Haven, CT 06520, E-mail: michael.crair@yale.edu; or Dr. Carol A. Mason, Department of Pathology and Cell Biology, College of Physicians and Surgeons, Columbia University, 630 W. 168th Street, 14-509 P\&S BIdg, New York, NY 10032. E-mail: cam4@columbia.edu.

DOI:10.1523/JNEUROSCI.1711-16.2016

Copyright $\odot 2016$ the authors $\quad 0270-6474 / 16 / 3610707-16 \$ 15.00 / 0$
}

disease. Although most of the participants were basic scientists, there was particular interest in identifying translational/clinical approaches to regeneration and in encouraging interchange between basic and clinical scientists. Finally, we will summarize the panelists' predictions on how long it may take to obtain functional recovery in humans, as this may serve an important reference point for future work in the field.

\section{State of the Field}

Guiding axons to targets: state of the field in uninjured and regenerating RGCs

Axon growth and guidance from retina to brain

Growth from the retina through the optic chiasm: receptors and ligands for navigating the midline. Numerous molecular factors instigate growth of RGC axons away from the retinal periphery and to the optic disc where they exit the retina into the optic stalk during normal development. Factors that inhibit growth toward the periphery include receptor tyrosine phosphatases, such as CRYP- $\alpha$, proteins of the Ig superfamily, including L1 and N-CAM, proteoglycans, and Slit-Robo signaling, whereas netrin-1 and its DCC receptor, N-CAM and laminin promote exit into the optic stalk (Brittis and Silver, 1995; Höpker et al., 1999; Thompson et al., 2006). Early postnatal RGCs injected intravitreally into adult retina readily extend axons to the optic disc, likely by using extant fibers as guides (Venugopalan et al., 2016), and providing a good prospectus for cell transplantation.

Since the discovery of axon guidance molecules in the last two decades, much is now known about the factors that direct RGC axon decussation at the optic chiasm midline. EphB1, a receptor expressed exclusively by ventrotemporal RGCs, interacts with ephrin-B2 on radial glia at the chiasm midline, resulting in repulsion of these RGCs from the midline toward an ipsilateral trajectory (Williams et al., 2003). In Xenopus, an EphB is expressed at 
metamorphosis when a small ipsilateral projection forms from ventral retina (Nakagawa et al., 2000). Shh and its binding partner BOC, expressed only in ventrotemporal RGCs, have also been implicated in forming the ipsilateral projection (SánchezCamacho and Bovolenta, 2008; Fabre et al., 2010).

The contralateral projection stems from RGCs positioned outside of the ventrotemporal crescent in the mouse, and from RGCs late in development from within the ventrotemporal crescent. The absence of a receptor for midline repulsion in these RGCs suggests that the contralateral pathway is a default pathway. Indeed, most phenotypes of mice lacking putative guidance factors maintain a contralateral projection, even if the ipsilateral projection is increased or misrouting occurs (Mason et al., 2014). Mechanisms for crossing the midline have been recently revealed: The noncanonical guidance factor VEGF acts via a neuropilin receptor to attract contralateral axons to the midline (Erskine et al., 2011). In addition, the inhibitory semaphorins have emerged as ligands at the midline that interact with their neuropilin and plexin receptors on contralaterally projecting RGCs in zebrafish and mouse: repulsion of the otherwise inhibitory semaphorins is overcome through interactions with $\mathrm{Nr}-\mathrm{CAM}$, as well as with cAMP, to effect midline crossing (Williams et al., 2006; Kuwajima et al., 2012; Dell et al., 2013). These studies presaged a new theme in axon guidance in which formerly distinct guidance receptors and their ligands act not only in parallel, but in combination and synergistically. Thus, in the spinal cord midline, Robo3 is a multifunctional regulator of pathfinding, mediating repulsion by the newly identified guidance cue NELL2, inhibiting Slit repulsion, and facilitating Netrin attraction (Jaworski et al., 2015). Similarly, growing motor neuron axons integrate both attractive and repulsive Netrin-1 signals together with repulsive ephrin signals (Poliak et al., 2016).

Axon organization in tracts beyond the chiasm. Axon order in central nervous system (CNS) tracts has been newly revisited on an anatomical and molecular basis, with the implication that pretarget organization is necessary for proper innervation into target laminae or subzones (e.g., Imai et al., 2009; Zhou et al., 2013). In the optic tract, RGC axons are organized chronotopically, retinotopically, by laterality of projection (ipsilateral vs contralateral), and by functional type (Torrealba et al., 1982; Guillery and Walsh, 1987; Chan and Guillery, 1994; Plas et al., 2005). In mouse, ipsilateral axons from ventrotemporal retina are cordoned off to dorsolateral tract, but are not fully in register with retinotopic divisions (Godement et al., 1984; Sitko and Mason, unpublished observations). Axons might sort by fasciculation or bundling of axons, one of the oldest axon guidance mechanisms in which grown cones track along other axons, as has been shown for regrowing axons (Lorenzana et al., 2015). Whether fasciculation of like axons is necessary for proper axonal growth and targeting, the identity of molecules on axonal surfaces mediating fasciculation of different cohorts, and to what extent regenerating axons would need to adhere to these organizational principles for successful targeting are at present unclear.

\section{A multitude of RGCs}

Morphological, functional, and genetic subtypes of RGCs. RGC subtypes have been characterized by classical anatomical techniques and through genetic lines obtained in GenSat screens; a number of these lines have allowed functional analysis of specific RGC morphological subtypes through the expression of fluorescent proteins with identified axonal projections to both imageforming and non-image-forming targets in the brain (Kim et al., 2008; Kay et al., 2011; Sanes and Masland, 2015; Sun et al., 2015).
New approaches, including calcium imaging and computational methods, such as "unsupervised clustering," indicate extensive functional diversity among RGCs (Baden et al., 2016). Single neuron gene expression techniques, such as DropSeq, promise to identify genes specific to each functional/morphological class (Macosko et al., 2015; Rousso et al., 2016).

RGCs can also be distinguished by expression of distinct transcription factors, for example, those that are upstream of differentiation and specific axon guidance programs determining laterality of projection. For instance, Zic2 regulates the expression of axon guidance receptors and other factors specific to RGCs with ipsilateral projections (Herrera et al., 2003; GarcíaFrigola and Herrera, 2010; Sánchez-Arrones et al., 2013). Brn3a and Islet2, the latter only in 30\% of RGCs, are considered markers of contralateral RGCs (Pak et al., 2004; Shi et al., 2013).

Different RGC subtypes have different times of generation and target innervations. As in other systems (e.g., Lodato and Arlotta, 2015), subsets of RGCs express distinct transcription factors and adhesion molecules that correlate with functional and anatomical subtype (Osterhout et al., 2011). RGCs that project ipsilaterally and contralaterally have distinct periods of neurogenesis (Dräger, 1985). Moreover, the timing of neurogenesis is closely linked to cell subtype and the targets they innervate (Osterhout et al., 2014).

These classic and newly emerging experimental techniques have led to the characterization of different classes of RGCs and can potentially be used to compare the regenerative capacity, targeting, and synaptogenesis phenotypes of RGCs across subtypes and species. This may provide fundamental insights into the rules and mechanisms modulating functional regeneration in the mammalian visual system.

Some RGC subtypes regenerate better than others. An exciting offshoot of the analyses described above is the demonstration that certain RGC subtypes appear to regenerate better than others (Duan et al., 2015). Alpha RGCs intrinsically have high mammalian target of rapamycin (mTOR) levels and also selectively express osteopontin and receptors for the insulin-like growth factor 1 . Among surviving RGCs after optic nerve crush, $\alpha$ RGCs account for nearly all RGC regeneration.

Generation of RGCs in vitro is not yet readily accomplished. Although much is known about how RGCs differentiate in vivo (Balasubramanian et al., 2014; K Jin et al., 2016; Kuwajima and Mason, unpublished observations; J Goldberg, unpublished observations), the molecular factors for directing precursor/stem cells into RGCs in vitro, and the order in which they must be expressed, have not yet been defined. Greater success has come from directing retinal "organoids" (retina-in-a-dish), derived from embryonic stem (ES) or induced pluripotent stem cells (iPSCs). This may be because multiple cell types and the retinal pigment epithelium, which contains many growth factors, are present in the organoids (Reichman et al., 2014).

Taking subtype specificity into consideration, characterizing the genes expressed in their native setting in development and maturity, as well as identifying the directives for differentiating stem cells into RGCs, will be important in attempts to reprogram stem cells to regrow for eventual transplantation into injured retina.

\section{Glia: help or hinder?}

Research on glia in regeneration has languished somewhat in recent years but has been most intensively studied in the spinal cord and should be revisited in the visual system. It has long been assumed that after injury, glia of all classes infiltrate and form the boundaries of scars, inhibiting axon regeneration (Gallo and De- 
neen, 2014). Less is known about glia in the optic tracts and how they respond to injury (Silver et al., 2015).

Immature glia are important for guiding axons during development. Immature midline glia in the optic chiasm and spinal cord express attractive (and repulsive) molecules essential for midline guidance (Mason and Sretavan, 1997; Lindwall et al., 2007). Ependymo-radial glial cells implement regeneration in the spinal cords of mature lower vertebrates (e.g., salamanders and fish) and may offer insights for understanding what can be done to resuscitate mature glia in the adult mammalian nervous system (Becker and Becker, 2015).

Are immature oligodendrocytes also growth-supporting? A new class of oligodendrocyte precursor cells, the NG2-expressing polydendrocytes, appear to give rise to oligodendrocytes. They are quite common in developing and mature brain and they give rise to oligodendrocytes and astrocytes. They proliferate at sites of injury, but their role in regeneration is just emerging (Hughes et al., 2013; Nishiyama et al., 2014).

Mature glia in the CNS. Whereas Schwann cells aid regrowth in the periphery in combination with endothelial cells and with fibroblasts (Parrinello et al., 2010; Cattin et al., 2015), mature astrocytes, as components of injury-induced scars, are thought to inhibit axon regeneration (Sofroniew, 2015). The cytokines CNTF/LIF enhance axon growth, but suppressor of cytokine signaling 3 (SOCS3) blocks cytokine signaling, especially in CNS astrocytes. If CNTF is expressed and SOCS3 knocked down, cAMP increases and RGC regeneration is enhanced (Smith et al., 2009). Recent evidence paints a more nuanced picture of the inhibitory effect of astroglia in scars on axon regeneration (Anderson et al., 2016). Astrocyte-scar formation can actually promote axon regeneration: the scar contains factors supportive of axon growth and addition of exogenous growth factors functions best when the scar remains at the site of injury. Other cell types in scars, such as pericytes and fibroblasts, although frankly inhibitory, are needed to seal injured tissue (Göritz et al., 2011). This work highlights the need for a more thorough understanding of the role of injury-induced scar formation and participating cell types in inhibiting, and promoting, axon regeneration.

Oligodendroglia have long been known to inhibit axon growth and regrowth after injury to the CNS. Neuronal receptors, such as NogoR, p75, and the paired immunoglobulin-like receptor B (PirB) interact with the myelin proteins Nogo, MAG, and oligodendrocyte-myelin glycoprotein and inhibit growth. Early attempts to instigate regeneration after spinal cord injury by blocking this interaction with antibodies against Nogo and genetically removing one or more of these receptors have met with mixed results. Currently, Nogo-A and its receptor NgR1 are regarded as negative regulators of neuronal growth, stabilizing CNS wiring at the expense of plasticity in later life and regeneration after injury (Schwab and Strittmatter, 2014). Bei et al. (2016) reported on another crucial aspect of oligodendroglia in regeneration: The inability of regenerating RGCs to produce behavioral recovery is in part the result of action potential "failure" in RGCs that have regenerated but lack myelin.

A variety of microglial cells in different stages, such as macrophages and microglia (resting and active), are present in the developing and mature brains (Bennett et al., 2016). Whether microglia function in axon growth and guidance during normal development is not clear, but they are key to synaptic pruning, as studied extensively in the dorsal Lateral Geniculate Nucleus (dLGN) during normal development (Hong et al., 2016). Macrophages were reported to implement axon growth following optic nerve crush by producing oncomodulin that in turn in- creases MAPK and JAK-STAT pathways in neurons. This scenario has been amended by findings that invasion of neutrophils, which also secrete oncomodulin, precedes macrophage accumulation in the retina after optic nerve injury (Kurimoto et al., 2013). The beneficial effects of macrophages were shown by expressing the chemokine CCL2 in uninjured dorsal root ganglion (DRG), which leads to an accumulation of macrophages and a conditioning-like response in neurite outgrowth (Niemi et al., 2016).

It will be important to learn more about the molecules expressed by glial cells and their receptors on neurons and develop avenues for manipulating them. This is particularly highlighted by studies on PirB, which is not only implicated in mediating growth inhibition by myelin but, like the NogoR, dampens synaptic plasticity in the visual cortex in adulthood (Atwal et al., 2008; Bochner et al., 2014).

\section{The cell biology of regenerating axons: intracellular triggers, cytoskeletal factors, retrograde signaling}

Transcription factors regulating growth in developing and mature settings. Great advances have been made in the dissection of intracellular signaling pathways that stimulate axonal regeneration, particularly in the identification of transcription factors and intracellular signaling pathways that can stimulate axonal extension after injury to the optic nerve or tract. This was recently reviewed for the retinal axon pathway (Benowitz et al., 2015) and for neurons in general, in a variety of model systems (He and Jin, 2016). Adult CNS neurons lack factors that implement growth in developing axons. GAP-43, a signaling protein that functions in developing axons, is in low supply in adult neurons. Axotomy leads to its upregulation in lower vertebrates but not in rodents (Kalil and Skene, 1986). A recent report identifies MASH1/Ascl1 as upstream of GAP-43 in zebrafish and in RGCs. After spinal cord injury, the combination of a Schwann cell bridge and viral delivery of Mash1 to enhance GAP-43 expression facilitates regeneration (Williams et al., 2015).

In the adult nervous system, mTOR regulates protein synthesis but is blocked by phosphatase/tensin homolog (PTEN). For $\alpha$ RGCs, downregulating PTEN can aid regeneration, which is further boosted by administration of osteopontin plus insulin-like growth factor 1 (Duan et al., 2015). The KLF transcription factors (Kruppel-like factors) KLF-4 and -9 suppress regrowth. In contrast, KLF-6 and -7 increase neurite outgrowth but are developmentally regulated (Moore et al., 2009). Thus, blocking PTEN or KLF4 has been a ready route to enhance optic nerve regeneration. New work demonstrates that the KLF16 regulates EphA5 expression in a methylation-sensitive manner (J Wang et al., 2016) and demonstrates the need to probe the molecular underpinnings of these and other growth-regulating transcription factors.

Combinations of treatments focusing on both neurons and glia, and intracellular signals. Treatments that target combinations of cells in the region of injury, their cytoskeleton, and signaling pathways appear promising (Benowitz et al., 2015). Stimulation of macrophages, either by lens damage or intravitreal treatment with zymosan, induces macrophages and other immune cells to secrete oncomodulin, thereby activating signaling and enhancing RGC axonal growth. Blocking PTEN in this model further enhances growth (Yin et al., 2003). A recent report indicates that zymosan increases accumulation of myeloid cells intravitreally. The dectin receptor is expressed on microglia and dendritic cells, but not RGCs, and intraocular injection of dectin increases regeneration similar to zymosan treatment. The Dectin-1 ligand is curdlan ( $\beta(1,3)$-glucan), necessary for downstream signaling and 
ultimately the growth-promoting effects of dectin (Baldwin et al., 2015). This route to optic nerve regrowth via immune system cells is promising, even though the mechanisms of RGC axon growth stimulation are not entirely understood.

An individual treatment can have opposite effects on different cells types: administration of a microtubule-stabilizing drug (epothilone B) stimulates axon growth and impedes scar formation by blocking fibroblast process formation and migration into the scar and simultaneously enhancing microtubule stabilization in growth cones (Ruschel et al., 2015).

In other recent work, doublecortin-like kinases (DLKs), in the MAP kinase signaling pathway, promote growth cone reformation after injury and neuronal survival (Nawabi et al., 2015). Activation of the DLK pathway by targeting the cytoskeleton induces a proregenerative state, enhancing axon regeneration in response to a subsequent injury in a process akin to preconditioning (Valakh et al., 2015). Further insight into axon regeneration has been made through the identification of signaling pathways in axon degeneration involving MAP kinases and Sterile $\alpha$ and TIR motif-containing 1 (SARM1) proteins; these pathways can be offset by increasing the $\mathrm{NAD}^{+}$synthetic enzyme NMNAT2 (Gerdts et al., 2015).

An important pathway for successful regrowth is signaling from the injury site back to the cell body (Rishal and Fainzilber, 2014). Local translation in the cut axon of importins and other proteins in association with dynein collaborate to retrogradely signal injury to the cell soma. This complex transports cargoes (including STAT3 and other transcription factors) that bind to both classical and nonclassical nuclear localization signalbinding sites on importins. Such signaling results in factors for regeneration to then travel anterogradely.

Just as some RGC subtypes are better at regenerating than others, DRG axons from the CAST/Ei mouse strain are much better at growing on myelin than DRGs from several other strains tested. This difference enabled the Activin transcript Inhba to be identified in a screen as being most correlated with this ability (Omura et al., 2015).

Studies revealing the basic cell biology of uninjured growth cones (Wada et al., 2016) and injured, regenerating growth cones (Bradke et al., 2012) have revealed how growth cones use cytoskeletal elements and calcium to turn, and to reform and grow after injury, respectively. Much of this work has been done in vitro. Studies using live imaging of growth cones during regeneration, as done in the spinal cord (Lorenzana et al., 2015) and in Caenorhabditis elegans (Kurup et al., 2015) but applied to the visual system, may reveal whether growth cones use different signaling systems to regrow compared to when they make their first foray into the terrain of the developing brain.

\section{Target engagement and synaptogenesis}

Getting axons to targets

The diversity and specificity of RGC targeting and the mechanisms regulating target engagement during development are only now being elucidated. Different classes (subtypes) of RGCs project to different brain targets; not all RGCs are created equal! (Baier, 2013; Dhande and Huberman, 2014). Regeneration of certain classes of RGCs may lead to reinervation of distinct targets, which could be a problem or an opportunity. For example, in the service of circadian function, a specific class of intrinsically photosensitive RGCs (so-called M1 type of ipRGCs) preferentially innervates the suprachiasmatic nucleus, but not the dLGN or superior colliculus (SC) (Chen et al., 2011; LeGates et al., 2014). In another remarkable example, each of three classes of direction-selective RGCs (which selectively respond to stimuli along different directional axes corresponding to the semicircular canals) project to specific nuclei in the accessory optic system (MTN, DTN, NOT) (Osterhout et al., 2015; Sun et al., 2015) to control eye movements that stabilize images on the retina.

Getting RGC axons to their brain targets seems to be the most difficult step in reconnecting the visual system. A large body of literature describes how growth cones grow within target regions to focus on the correct retinotopic position. The chemoaffinity process of Sperry and by Bonhoeffer posits that there are fixed affinities between axon growth cones and targets, based on gradients of target-derived molecules, and now known to be modified by neural activity (Luo and Flanagan, 2007). New analyses, both experimental and theoretical, argue for fiber-fiber affinities, along with adaptation mechanisms, rather than strictly gradientsensing for retinotectal map formation (Suetterlin and Drescher, 2014; Weth et al., 2014), making for an even more stringent goal for regenerating axons.

Much is known about the regulation of RGC synaptogenesis in the thalamus (Hong and Chen, 2011; Hong et al., 2014; Lee et al., 2014; Dilger et al., 2015) and SC (Shah and Crair, 2008; Furman et al., 2013), where broadly speaking hyperinnervation and synapse elimination serve to refine connectivity to generate mature functional circuits. Specific steps in development likely require not only cell type and laminar specificity in the dLGN and SC, but also subcellular specificity (e.g., proximal not distal dendrites) (Wilson et al., 1984). As for most regions of the nervous system, the molecules implementing targeting of specific layers are not well understood, but the best documented is for the optic tectum in zebrafish (Baier, 2013; Robles et al., 2014).

RGC synaptogenesis during development is activity-dependent, such that the presence, absence, or pattern of spontaneous activity and visual experience shapes synapse formation. It is at present unclear how activity will affect regenerating and reconnecting RGC axons in the dLGN/SC. Interestingly, the organization of afferents and synapses of direction-sensitive RGCs in the developing zebrafish optic tectum into layers or laminae is not required for tuning of tectal cells, as tectal dendrites undergo structural plasticity to compensate for the mistargeting. However, functional responses are greatly delayed, suggesting that proper lamination of the target to receive RGC inputs is ultimately necessary for rapid circuit assembly and the generation of proper responses to stimuli (Nikolaou and Meyer, 2015). Synaptic machinery is present during regeneration but can inhibit regrowth (Brace et al., 2014; Tedeschi et al., 2016). Likewise, activity appears to impede regeneration of peripheral nervous system (PNS) neurons, with the cessation of electrical activity after peripheral lesion contributing to the regenerative response observed upon conditioning (Enes et al., 2010). Very recently, neural activity was shown to powerfully, and positively, modulate the anatomical and functional regeneration of RGCs following experimentally induced optic nerve trauma (Lim et al., 2016). Thus, compared with initial development, it remains much less certain how and to what extent RGC activity contributes to axon regeneration and functional reintegration.

That regenerating axons can reform synaptic connections in their targets has been known for decades, from the remarkable experiments of Albert Aguayo in the 1980-1990s, in which lengths of peripheral nerve were ligated onto the transected optic nerve, drawn over the pia (skull), and inserted into the SC. Functional recovery was seen in RGC axons that grew into the graft. More recently, synapse formation of transected RGC axons with- 
out the aid of nerve grafts was also achieved, but these axons were cut quite close to the SC (Bei et al., 2016).

\section{Visual system plasticity}

Maximizing plasticity in the adult visual system as a therapeutic approach to functional recovery following RGC disease or trauma is conceptually appealing on two fronts. First, even if substantial RGC axon regeneration and functional reintegration to the brain are not achieved, facilitating plasticity of the visual system to make maximal use of remaining (nonregenerated) RGC connections could offer significant therapeutic potential. Second, even when RGC regeneration and functional reintegration to the brain are achieved, activity and experience-dependent plasticity of visual circuits in response to reinnervation will likely play an important, if not critical, role in achieving maximum behavioral recovery of visual function. The intrinsic mechanisms regulating plasticity in the visual cortex are becoming progressively better understood, and several excellent recent reviews exist on the subject (e.g., Espinosa and Stryker, 2012; Takesian and Hensch, 2013). Visual cortex plasticity in response to the effects of monocular deprivation, a classic model of visual system plasticity, is mediated by a decrease in closed eye response followed by an increase in open eye response driven through synaptic changes in specific neural circuit elements (Espinosa and Stryker, 2012).

A fundamental framework for examining visual system plasticity is the concept of developmental windows or "critical periods" for adaptive plasticity in response to changes in visual experience. Opening of the critical period for ocular dominance plasticity is governed by the emergence of intracortical inhibition (Fagiolini and Hensch, 2000; Takesian and Hensch, 2013) and is genetically regulated (Kobayashi et al., 2015). It is ever more apparent that critical periods are not a strict process, and substantial cortical plasticity lingers even in adult humans (Kalia et al., 2014), although the degree to which adults are susceptible to the effects of experience dependent manipulations is clearly reduced relative to juveniles, and the mechanisms mediating aged forms of plasticity are only partially overlapping with juvenile plasticity (Espinosa and Stryker, 2012; Nahmani and Turrigiano, 2014). Mechanisms responsible for critical period closure are not as well understood. Models to manipulate the developmental plasticity window to restore vision in the adult are being actively investigated, and some progress has been made in this regard (Espinosa and Stryker, 2012). For instance, transplantation of embryonic inhibitory interneurons to the adult visual cortex restores ocular dominance plasticity in mice (Southwell et al., 2010; Tang et al., 2014; Davis et al., 2015).

A number of other strategies have been proposed to extend or reopen the critical period for cortical plasticity, including modulation of proteins typically associated with the immune system but increasingly implicated in nervous system plasticity (Bochner et al., 2014), suppressing inhibitors of regeneration associated with myelin (NogoRs) (McGee et al., 2005), trophic factors (Berardi and Maffei, 1999), and breakdown of the extracellular matrix to promote plasticity (Pizzorusso et al., 2002). Targeted manipulations of cortical inhibition, along with manipulations that promote homeostatic rescaling and synaptic plasticity, may prove particularly effective at reintroducing conditions that promote adult cortical plasticity in the context of peripheral injury and RGC regeneration.

Subcortical visual areas may also be targets of regenerative plasticity, but plasticity in these visual areas, such as the dLGN and SC, is less well understood than for the cortex. Classically, the LGN and the SC, like the retina, were thought not to be sensitive to developmental visual experience; however, that view has changed somewhat over recent years (Hooks and Chen, 2007). In the SC, maintenance of normal visual receptive field properties appears to depend on visual experience, but it is not clear whether the degradative plasticity associated with visual deprivation persists in the adult (Balmer and Pallas, 2015). Also, in the dLGN, there appears to be a period of susceptibility to the effects of visual deprivation that is similar to that in V1, but whether the plasticity is absent in the adult, or what the mechanisms are that mediate this plasticity, are very incompletely understood (Jaubert-Miazza et al., 2005; Hooks and Chen, 2006, 2008). Future hopes of functional integration of regenerating RGC axons into visual targets, like the $\mathrm{dLGN}$ and SC, would seem contingent on a better understanding of the normal development of these connections and their receptiveness to innervation by regenerating RGCs.

Encouraging evidence that functional connections can form after retinal axon terminal degeneration comes from a recent report that after SOCS3 and PTEN deletion, demonstrable RGC axon regeneration, retinocollicular synapse formation, and some functional recovery were achieved if axons were cut distally very near to their targets in the SC (Bei et al., 2016). Although these distal injuries are not very clinically relevant, they demonstrate that at least some synapses will form if RGC axons can be persuaded to regrow into their normal brain targets.

\section{Model systems for comparison with mammalian visual system regeneration}

Fundamental insights about mechanisms limiting or promoting $\mathrm{RGC}$ regeneration and reconnecting to the brain may be inspired by examining similarities and differences with other model systems, mammalian (spinal cord regeneration), lower vertebrates (RGC regeneration in fish, frogs) and worms.

\section{Spinal cord injury}

There is a long and rich history of research in the field of spinal cord regeneration, a problem that shares many common features with RGC regeneration, as it is a CNS pathway and a relatively common site of traumatic injury (Schwab and Bartholdi, 1996; Liu et al., 2011). Intracellular signaling pathways that promote spinal cord regeneration often overlap with those in RGCs (e.g., PTEN/mTOR; SOCS3/Jak-Stat) (Liu et al., 2011) and KLF (Moore et al., 2009; Blackmore et al., 2012). Thus, large-scale screens for factors that promote spinal cord regeneration are likely also to be informative for RGC regeneration. Similarly, exogenous factors that inhibit spinal cord regeneration such as Nogo receptor ligands (Schwab and Strittmatter, 2014), may play a similar role inhibiting RGC regeneration (X Wang et al., 2015) but have only had limited investigation in the visual pathways.

The field of spinal cord regeneration benefits from a standardized and easily quantitated scale to assess the recovery of motor function in rodents, the Basso, Beattie and Bresnahan scale for rats (Basso et al., 1995) and a similar measure for mice (Basso et al., 2006). Although in some ways incomplete and imperfect, leading to a number of articles encouraging investigators to exercise caution (Steward et al., 2003; Tuszynski and Steward, 2012), standardized scales do allow for much easier comparisons of treatment efficacy across animals and studies. RegenBase, a publicly available knowledge base that uses "consistent identifier schemes and data representations that enable automated linking among RegenBase statements and also to other biological databases and electronic resources" (Callahan et al., 2016), also encourages investigators to adopt standardized experimental and analytic strategies to examine spinal cord injury. Standardized experimental outcome measures for visual functional recovery, 
in combination with careful electrophysiological and anatomic analysis of RGC axon regeneration and synapse formation, could prove to be a catalyst to studies of regeneration in the visual system.

Recovery from spinal cord lesions is closely linked to rehabilitation training, either through direct electrical stimulation (Hamid and Hayek, 2008) or physical therapy. Visual training also appears to enhance functional optic nerve regeneration in the lizard (Beazley et al., 2003). This has been little studied in the mammalian visual system, but the available evidence suggests that training facilitates recovery following visual deprivation ( $\mathrm{He}$ et al., 2007; Li et al., 2011; Kaneko and Stryker, 2014), which further suggests that appropriate visual training paradigms in combination with genetic or pharmacological strategies may maximize vision recovery when RGC axon regeneration is achieved.

\section{PNS}

There are also important lessons to be learned from studies of PNS regeneration. In an excellent use of gene profiling, bioinformatics, and systems biology, alterations in genes during CNS regeneration versus PNS regeneration were analyzed (Chandran et al., 2016). From the information gleaned, a drug was identified that enhanced optic nerve regeneration.

The retina and retinotectal system in lower vertebrates is fully regenerative even in the adult. Why is the mammal different, and what can be learned from this comparison (Ruthazer and Cline, 2004; Araki, 2014)? Complete recovery is possible in the retinotectal systems of fish and frogs. This demonstrates that, if RGCs are in an environment that is permissive for regrowth, they can regrow and a fully functional circuit can reform. Regeneration is not accurate initially, but over time, mistargeted axons are selectively retracted (Fraser and O'Rourke, 1990). Chemoaffinity cues (e.g., Eph/ephrins) may be preserved, and in some cases upregulated following denervation (King et al., 2004; Rodger et al., 2004), a process that should be better understood in mammals (Rodger et al., 2001; Symonds et al., 2007). However, newly discovered limitations on regeneration in amphibians after mechanical injury to the pallium include a failure to reestablish longdistance axonal tracts and circuit physiology, even though newborn neurons can position themselves within altered tissue architecture (Amamoto et al., 2016).

Lessons can be learned from work on fish and frogs on intracellular signaling and transcriptional control of growth in RGCs. The same "brakes" on growth (e.g., SOCS3) are operative, but they are overcome by regeneration-promoting molecules such as cytokines (Elsaeidi et al., 2014). In addition, the transcription factors KLF6 and KLF7, which enhance optic nerve regeneration in mammals, were indeed first identified in fish (Veldman et al., 2007). Moreover, during regeneration, activity may play a more important role than during development (Ruthazer and Aizenman, 2010), as has been recently shown in mammals (Lim et al., 2016). Thus, the ability of RGCs to regenerate in lower vertebrates should be used as a resource to identify growth-supporting and inhibitory factors that operate in mammals, and to stimulate an optimal balance of the two kinds of factors.

Other model systems (e.g., C. elegans, Drosophila, zebrafish) offer the potential to dramatically expand potential genetic targets for increasing the regenerative capacity of RGCs in the mammal. In zebrafish, for example, the glycosyltransferase lh3 (Isaacman-Beck et al., 2015) was identified to implement targetselective regeneration in the periphery by interacting with collagen to destabilize mistargeted axons.
In C. elegans models of regeneration (Hammarlund and Jin, 2014; Nix et al., 2014), single neurons can be imaged, transected, and screened after injury with greater ease than in vertebrates. Principles gleaned include that multiple genes influence growth, and as in higher animals, that specific neurons have different regenerative capacity. Importantly, the DLK-1 MAP kinase pathway and other MAP kinase pathways, as well as the CELF family RNA binding protein UNC-75 involved in synaptic protein splicing (Chen et al., 2016), are conserved. Thus, such studies form a node from which many genes involved in injury signals, membrane dynamics, growth, and synaptogenic factors have been identified, serving as another important resource for examining vertebrate regeneration. C. elegans lacks glia, so gene pathways regulating regeneration are acting in neurons, which simplifies the interpretation of experiments in this model system, but obviously the role of glia-derived factors in promoting or inhibiting regeneration cannot be assayed.

\section{The Future}

\section{Biological and conceptual barriers to progress}

There are a number of barriers preventing the functional regeneration of RGC connections to the brain (Fig. 1). Overarching challenges that to date have few answers, but are crucial for implementing regeneration of RGCs, include the following:

To what extent does regeneration recapitulate development? How can researchers relate developmental aspects of axon guidance and targeting to regrowth of axons in the mature brain? Many investigators use development as a model system for regeneration, but the adult axon and milieu are very different from the circumstances in development. Which developmental mechanisms can operate in the adult state after injury? Even in developing systems, neurotrophins can act differently on RGC dendrites than on axons in the target (Lom and Cohen-Cory, 1999), and guidance factors, such as netrin, act differently depending on the stage of development (Shirkey et al., 2012). Moreover, upregulation of Eph receptors in the retina and ephrins ligands in the SC after optic nerve injury in the adult is accompanied by upregulation of ephrins in astroglia, offsetting the beneficial recapitulation of developmental expression in RGCs and their target (Symonds et al., 2007). So considerable uncertainty remains about the relevance of studies of RGC axon development to regeneration. On the one hand, attempting to recapitulate development during regeneration may be a reasonable therapeutic strategy, on the other, we only have a superficial understanding about the similarities and differences between conditions present during development and regeneration in the adult.

The optic chiasm seems to be a blockade to successful axon growth to targets. As discussed by Diekmann et al. (2013), this conclusion is controversial. The Benowitz group (de Lima et al., 2012) injected CNTF intravitreally, combined with conditional PTEN and SOCS3 deletion in RGCs or zymosan-induced inflammatory stimulation, together with cAMP analog injection, and observed more axonal advance into the optic chiasm after optic nerve crush than in most studies up to that time. When this experiment was repeated (Luo et al., 2013) and the brains cleared, growth was indeed observed into the optic chiasm, but substantial misrouting was evident, few axons entered the optic tract and no labeled axons reached their targets in the thalamus, pretectum, or SC. Some functional recovery was observed with the combinatorial treatment paradigm in Lim et al. (2016), but other plasticity mechanisms or experimental differences may have been at play. In a recent study, increasing activity in adult-injured RGCs leads 


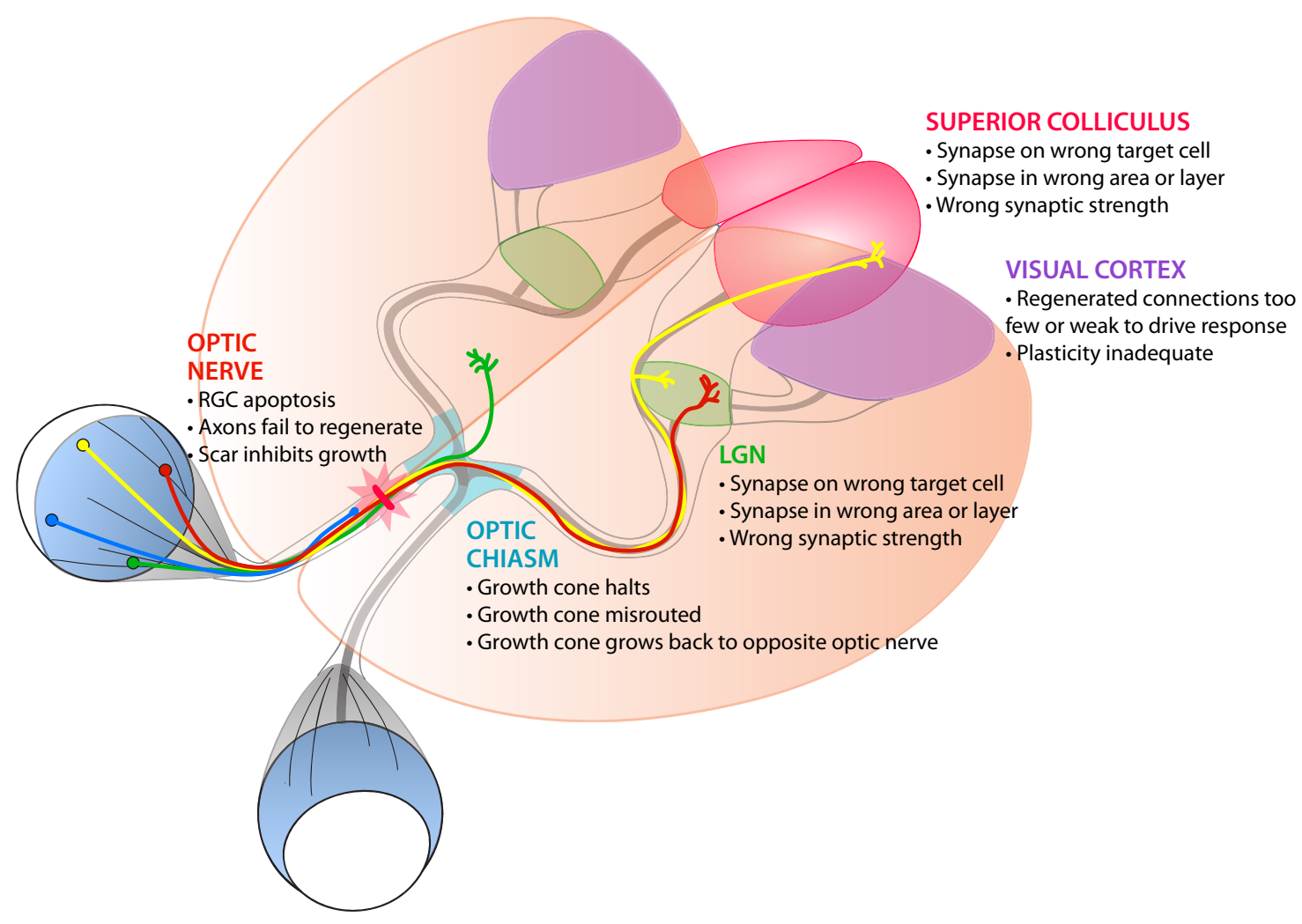

Figure 1. RGCs encounter a number of barriers to regeneration following injury or trauma. In the eye, a range of factors, including cell-intrinsic transcription factors and receptors as well as exogenous growth factors, influence RGC survival and the ability of cells to generate axons and grow out of the eye and into the optic nerve. Some classes of RGCs show greater regenerative ability than others. In the optic nerve, supportive glia may not be present in the adult, and inhibitory influences associated with the scar block regeneration (blue axon). At the optic chiasm, growth cones are often misrouted toward the hypothalamus (green axons), or grow back into the opposite optic nerve, or halt completely. In the LGN and SC, if axon guidance factors are sufficient to guide the axons to these targets, synapses may form in the wrong retinotopic area, layer, or target cell. Synapse strength may also be inappropriate to mediate functional connections. In the visual cortex (and to a certain degree in the $S($ and LGN), regenerated connections may be too few or too weak, and circuit plasticity may not be adequate to compensate to generate useful functional response.

to extension of a few axons through the optic chiasm. In another recent report, after delivering young RGCs intravitreally into uninjured adult rat retina, a small number of RGC axons were observed to grow past the chiasm and terminate in targets (Venugopalan et al., 2016). The latter finding holds promise that transplanted RGCs have the capacity to grow through the optic chiasm, especially when not blocked or impaired by an injury site, but both studies confirm that the adult optic chiasm is a difficult zone for many RGC axons to traverse. The field therefore needs to carefully chronicle the guidance systems that exist in the adult visual pathways, especially at the optic chiasm, in the resting state and after injury, to enable midline cells and the molecules they express to facilitate growth and projection through the chiasm.

Better models are needed, especially for visual pathway regeneration. Establishing a readily reproducible and standardized lesion model, particularly one that more closely mimics typical injuries to visual pathways in the adult human, would dramatically facilitate progress in the field. Assessing regeneration should be quantifiable and repeatable; more complete and robust anatomical assays to detect and measure axon growth and functional assays to probe restoration of vision are needed to speed progress.

Why do different $R G C$ types have different regenerative capacities? Can we use what is different about RGC subtypes that have high regenerative capacity to promote regeneration in general? Given the diversity of RGC subtypes, and in the context of RGC replacement, how can we identify, isolate, and enrich for specific subtypes of RGCs. For instance, can we use human ES cell- or iPSC-derived organoid cultures (Nakano et al., 2012) to determine what subtypes can be generated?
Plasticity in upstream circuits ( $d L G N$ and cortex) could be crucial for effective functional recovery. Promoting plasticity in upstream cells and circuits to counteract the effects of RGC injury is a particularly promising avenue of future investigation. Likewise, some focus on the status of RGC target areas and ways to keep them healthy while degenerative and regenerative processes are occurring, is likely crucial to maximize functional recovery. For example, recent studies demonstrate significant degeneration in the dLGN and visual cortex in human patients with glaucoma and other retinal degenerative conditions (Prins et al., 2016). Some central atrophy may actually occur early and contribute to the progression of the disease, highlighting the importance of promoting dLGN and visual cortex plasticity to combat peripheral visual loss (Yücel et al., 2003).

How many neurons must regenerate to obtain useful visual function? Experiments suggest that $<10 \%$, perhaps as little as $5 \%$, of corticospinal tract axons need to regenerate to produce significant functional recovery (Bregman et al., 1995). Furthermore, preservation of as few as $1 \%-2 \%$ of corticospinal tract axons in lesion models is sufficient to maintain nearly normal function ( $\mathrm{Li}$ et al., 1997). This suggests that the number of connections needed to maintain visual function versus restoring function are not the same, and a relatively small number of RGCs may lead to sufficient behavioral recovery of vision. Moreover, substantial patient benefit may be gained by promoting modest RGC regeneration to non-image-forming brain regions, such as the suprachiasmatic nucleus, as loss of retina-driven circadian function is associated with mood disorders, such as depression (LeGates et al., 2012). 
Topography and circuit specificity. Recovery of object discriminative capacity (form vision) likely requires not just target reinnervation, but the formation of quite specific patterns of connectivity, as it is difficult to imagine how a random mosaic of projections from RGCs onto target areas could provide an interpretable image. The same issue applies to the different subpopulations of RGCs connecting to specific targets: is this necessary? Or can we learn about what drives this specificity to enhance regeneration?

\section{Technical advances: ideas for new approaches and opportunities}

Advances in imaging of live tissue after injury should yield good, quantitative assays to assess degeneration and regeneration of axons and to chronicle morphological and functional recovery. Tissue clearing and new microscopy techniques that circumvent the need for histological sections (and loss of 3D information, such as axon trajectories in the context of the whole organism) are expected to provide information about what is actually taking place, as opposed to artifact-plagued in vitro approaches (Richardson and Lichtman, 2015).

Imaging regenerating axons and receptor/ligand disposition. Live imaging has revealed the behavior of regenerating axons in C. elegans and the vertebrate spinal cord (Byrne et al., 2011; Lorenzana et al., 2015); similar studies should be performed in the visual system. Exciting advances, including the use of pHluorins, will enable visualization of receptor dynamics on the growing axon (Delloye-Bourgeois et al., 2014).

There are likely many more guidance molecules to be discovered. A glycerophospholipid (lyso-phosphatidyl- $\beta$-D-glucoside) is involved in regulation of modality-specific repulsive guidance of spinal cord sensory axons (Guy et al., 2015). The heme protein neuroglobin is upregulated after injury to the optic nerve in zebrafish in which axons readily regenerate, but downregulated in mouse RGCs; these findings could point to this factor as a stimulant of regeneration for higher vertebrate RGCs (Sugitani et al., 2016).

New intracellular signaling pathways and guidance molecules are being discovered through high-throughput screens; these molecules could be blocked or stimulated after injury. For example, inhibitors of protein prenylation, such as statins, can accelerate axon growth in an optic nerve crush model and can also implement axon sprouting at the neuromuscular junction, an inroad into therapies for ALS (Li et al., 2016). In a similar vein, an unbiased RNAi gene-silencing screen has revealed that Inpp5f (Sac2) is a phosphatase suppressor of injury-induced CNS axon growth (Zou et al., 2015). Rtca (RNA 3'-terminal phosphate cyclase) is an inhibitor of axon regeneration and, when blocked, can implement regeneration in Drosophila and in the mouse retinal axon pathway (Song et al., 2015). And, STAT3 is a transcription factor that translocates to mitochondria in mature CNS neurons upon cytokine stimulation (Luo et al., 2016).

Viral/genetic/pharmacological approaches. Viral/genetic/pharmacological approaches are particularly advantageous for vision researchers because it is much easier to deliver viral vectors and reagents to the eye, a confined capsule that is accessible, than to other parts of the CNS. Researchers should explore ways to combine the optogenetic and optopharmacological techniques to stimulate neurons and implement axon growth and synapse formation, as has been done after transplanting ES cell-derived motor neurons to control restoration of function (Bryson et al., 2014). Optogenetics has also been used to activate guidance receptors (Endo et al., 2016).
Nanoscale tissue scaffolds hold the promise of implementing regeneration along with surgical microsplicing but has not been applied to the visual system (Chang et al., 2010).

Transplantation/replacement of RGCs into the retina. Stem cells, especially human iPSCs, will be an important and powerful tool for human regeneration. Cellular reprogramming using synthetic mRNA molecules has yielded RGCs, one of the first successes in the field (Sridhar et al., 2016).

Young RGCs can be injected intravitreally, settle on the retina, and grow axons to the brain (Venugopalan et al., 2016). It would be interesting to peel back the inner limiting membrane and directly place RGC progenitors on the RGC layer to see how they would behave, or conversely, take adult ganglion cells and introduce them into an embryo to explore environment versus cell differences. An important question is whether to transplant dissociated cells or "pieces" of retina grown in a dish (Nakano et al., 2012).

Müller glia may provide a source of endogenous stem cells for replacing damaged RGCs. In fish, such transdifferentiation normally occurs in response to injury, involving intrinsic reprogramming that produces proliferating progenitors having the ability to regenerate all major retinal cell types and restore vision (Goldman, 2014). When the transcription factor Ascl1, important for regeneration in fish, is transgenically expressed in young but not adult Müller glia, these glia can give rise to amacrine and bipolar cells and photoreceptors in response to injury (Ueki et al., 2015). This work points to the proneural transcription factor Ascll as one difference in regenerative potential, and indicates that the reduction in reprogramming potential is associated with progressive limitation to the accessibility of progenitor gene cisregulatory regions.

Using in vitro assays to see how retinas from different animals behave and whether they recapitulate in vivo biology would provide an easier way to get cross-species information than in vivo work. For example, developing in vitro coculture preparations of afferent tissue-target tissues would help explore the criteria for retinal afferent target interactions.

\section{Gaps in knowledge of basic features of RGCs and the regeneration landscape}

A pressing question at the National Eye Institute Satellite meeting was whether the questions/gaps in our knowledge of how to stimulate RGC regeneration can and should be tackled through nonhypothesis driven research. The participants thought the following areas need to be addressed, both for recovery of function in the visual system and in damaged CNS in general.

\section{Axon growth, guidance, and targeting}

What are growth cone behaviors along different loci in pathways, especially in targets, in normal development and regeneration in the adult? Live imaging of RGC axons extending in the normal developing optic chiasm and along the visual pathway reveals that RGC growth cones advance more slowly in the chiasm, and repeatedly extend and retract before traversing the midline and entering targets (Harris et al., 1987; Godement et al., 1994; Sakai and Halloran, 2006). Live imaging of the chiasm after optic nerve injury would elucidate where the barriers are for regenerating RGC growth cones.

Studies in Drosophila and other model systems indicate that interactions of essentially every surface of a growth cone helps determine what it does. Adhesion and other molecules (Tan et al., 2015), some of them newly discovered, implement various steps in targeting and synapse formation, others involving overshoot- 
ing, retraction, and changes in morphology, before synapses are made (Özel et al., 2015). Understanding growth cone surfaces and the molecules they express is critical to knowing whether they provide opportunities or obstacles for driving regeneration.

Which ECM molecules, guidance receptors and ligands are expressed in the adult, in "resting" states compared with after injury or after manipulation of intracellular signaling?

What adhesion molecules made by mature neurons interface with those on regenerating axons, and how do mature neurons use these molecules?

\section{Fasciculation}

Because no growth cone acts alone, understanding the molecular control of fasciculation during growth at each locus is important for researchers to understand how to manipulate fasciculation in the context of regeneration.

Studies are needed on molecules that are important in topographic map formation in mammalian systems. Which of these are used for fiber organization in the optic tract and/or axon guidance at other sites along the pathway, such as the optic chiasm?

In spinal cord injury, there is often incomplete injury and sprouting, or collateral growth, from uninjured axons that may be an important aspect of the anatomical changes that underlie behavioral improvement. Does this have any relevance for optic nerve regeneration and, if so, at which site(s)?

\section{Cell type-specific differences}

The different subtypes of RGCs that have been characterized to date have different functional properties and transmit visual information to different targets, have different regenerative potential, and respond differently to manipulations meant to encourage regeneration.

This is both a problem and an opportunity. RGC subtypespecific differences in regeneration provide the perfect internally controlled system. Cell types that are just microns away from each other and essentially confront the same landscape differ dramatically in their abilities to survive and to regenerate. RGC subtype specificity often has to do with both the specific genes expressed and the cells they are connected to in their targets. It is also important to understand each of the subtypes and how they function to help guide development of relevant functional assays. Taking aspects of subtype specificity into consideration will be important in attempts to reprogram stem cells to regrow.

The majority of ganglion cells in the fovea are midget ganglion cells. Are there ways of humanizing a mouse model to result in something more similar to a parvocellular system? One could imagine making a mouse with midget ganglion cells and also evaluating the capacity of midget or midget-like ganglion cells to regenerate in a dish. Gene profiling or comparative transcriptomics should be done to compare rodent, primate, and, ideally, human ganglion cells.

It would be useful to have baseline knowledge about how many RGCs need to be rescued to restore visual function and which types need to be rescued. Would focusing on RGCs that are more naturally prone to regenerating be sufficient to improve function, or is it necessary to learn how to promote regeneration of types that do not do so readily? Basic studies should be performed to identify the functional role of distinct RGC subtypes to determine how many can be eliminated and still have sufficient visual capacity to meet defined criteria.

Mice are used extensively for cell and molecular studies on regeneration. What behavioral assays should be developed to test recovery of function, for image-processing and non-imageprocessing RGCs, such as the intrinsically photosensitive RGCs (Prusky et al., 2004; Schmidt et al., 2014)?

It is not well understood what happens within the retina to RGCs whose axons are damaged, or to other retinal neurons when they are lesioned. Do dendritic processes of surviving RGCs after optic nerve injury "fill in" vacated territory? For example, zebrafish horizontal cells prefer to contact ultraviolet cones; after damage to these cones, horizontal cells retract their dendrites and reconnect specifically with ultraviolet and not other cone types (Yoshimatsu et al., 2016).

\section{Comparison of information gained from model systems with} vertebrate visual systems

Use of some of the very simple model systems may help researchers tackle the issue of the minimum number of regenerated neurons needed to restore vision incrementally.

Genetic screening in C. elegans is identifying a large number of new genes that affect axon regeneration, including ones having novel function. Different cell types exhibit different regeneration patterns, at different times (e.g., a particular gene with inhibitory activity during development might promote axon growth during regeneration), and depend on different factors. Many of these genes are homologous with vertebrate genes (see Model systems for comparison with mammalian visual system regeneration).

The classic fish and frog regeneration model system, in which functional vision is restored, has not been adequately studied with modern genetic and imaging tools. For example, creating transparent adult zebrafish model systems (through gene targeting to get rid of pigmentation) would allow researchers to use the newest imaging techniques to watch ganglion cells regenerating, perhaps using transgenic lines to mark specific types of ganglion cells and other cells encountered in the pathway during regeneration.

A simple assay using "shelf screening" of existing zebrafish mutants generated by the Sanger Institute for defects in optic nerve regeneration has identified mutants that do not have developmental phenotypes but clearly have a phenotype in regeneration.

\section{Glia}

Not all glia are equal, and there is much heterogeneity even among the "good" glial cells in the peripheral nervous system, where there is much heterogeneity between the different subtypes of Schwann cells.

Visualizing multiple cell types and their interactions during degeneration and regeneration, such as how macrophages and glial cells interact with injured neurons, would be a powerful tool and help develop testable hypotheses.

What drives remyelination, important for nerve conduction and function? Bei et al. (2016) suggest that enhancing axon conduction during regeneration, even in the absence of myelination, can enhance regeneration and functional recovery. Perhaps this can substitute for the absence of myelin during regeneration. Some experimental paradigms for stimulating regeneration have produced remyelination of axons, but others have not; a transcriptional comparison might reveal interesting responsible molecules. Activity in the ganglion cells might be important for recruiting the oligodendrocyte precursors for wrapping, but that has not been tested. In zebrafish, when axons regenerate spontaneously, remyelination occurs mostly when the axons have reached their targets and make synapses. Is there a correlation between remyelination and synapse formation in other models? 
Genes, “-omics”: exploratory listmaking

We need a more complete landscape analysis, including the transcriptome of growing RGCs themselves (and proteomics) of the cells they grow on. The transcriptome of DRG neurons after injury was analyzed and a drug identified that implements regeneration in both DRGs and RGCs (Chandran et al., 2016). Likewise, genomic approaches to identify genes expressed in the growth cone of regenerating axons compared with growth cones on developing axons (Zivraj et al., 2010; Tan et al., 2015) would be informative, as has been done in comparing RNAs locally translated in axons of developing and adult RGCs (Shigeoka et al., 2016).

\section{Synaptogenesis and plasticity}

Getting the axon to the brain seems the hardest part of reconnecting the visual system, because neurons seem to like to make synapses once they've reached their target, and there is extensive synapse and circuit plasticity once connections are formed.

Perhaps just being able to regenerate any type of RGC, such as $\alpha$ RGCs, would be sufficient to produce visual function (e.g., not bumping into walls) because there is extensive plasticity at the synaptic level in the CNS. Studies of the visual cortex show inhibitory regulation of synaptogenesis and plasticity in the adult visual cortex, and those brakes can be removed. How plastic are different types of ganglion cells? Would it be possible to use their capacity to regenerate, but modify the type of vision they communicate to the different targets? If activity and visual experience play a role in these types of events, might researchers be able to use those elements to help expand the possibilities of visual recovery?

Studies are needed to investigate how much plasticity there is in thalamic or tectal targets. In addition to CNS plasticity, there may also be vision-dependent plasticity in the retina. Can compensatory mechanisms in the retina contribute to recovery? Exploring how the receptive field properties of the postsynaptic neurons change or recover might provide a middle ground between regeneration and behavior. Optical techniques or multielectrode array recordings can give information about how receptive field properties change when specific cell types are removed, whether receptive field properties recover with regeneration, and which types of receptive fields are restored.

Are there features in the target that might promote regeneration through retrograde factors? If mice develop without a cortex or without cortical layer 6 axonal projections, retinal axons fail to target the dLGN but still target the suprachiasmatic nucleus, olivary pretectal nucleus, and SC. These results imply a feedback mechanism specifically for the axons that are projecting to the cortex. These results provide support for a new mechanism of target selection, whereby descending cortical axons provide an activity that promotes feedforward targeting of RGC axons to the thalamus (Shanks et al., 2016). On the other hand, RGCs have partial influence on the development of geniculo-cortical neurons: in the absence of retinal input, relay cells undergo the usual exuberant dendritic growth and branching, but branches are then eliminated and dendritic field size is attenuated, even though basic membrane properties and firing characteristics appear to be maintained (El-Danaf et al., 2015).

\section{Relationship between synaptic proteins and regeneration}

Are the processes of elongation and synapse formation at odds with one another (Tedeschi et al., 2016)? SkpA, a core component of SCF E3 ubiquitin ligases, and the E3 ligase Highwire limit MAPK signaling, and are important for synaptic development and axon maintenance in degeneration and regeneration (Brace et al., 2014).
Relationship between degeneration and regeneration

What is the role of inflammation in regeneration? Augmenting the inflammatory reaction in the eye after optic nerve injury is very proregenerative, but studies in the spinal cord suggest that inducing inflammation is a double-edged sword (X Jin and Yamashita, 2016). New work points to upregulation of mesencephalic astrocyte-derived neurotrophic factor in innate immune cells after retinal injury; this factor promotes neuroprotection and tissue repair and improves photoreceptor-replacement therapies (Neves et al., 2016), illustrating the need to understand cross talk between CNS glia and the immune system.

Protection of RGCs is a precondition for regeneration because, in the absence of treatment, RGCs begin to undergo apoptosis 4-5 d after optic nerve injury. However, some molecular manipulations increase RGC survival but do not support regeneration (Watkins et al., 2013), so we should not assume that a given neuroprotective treatment will promote regeneration and restoration of function (Fu et al., 2011; Vigneswara et al., 2015; Peng et al., 2016).

\section{Translational and clinical perspectives: issues and ideas}

Interdisciplinary engagement between basic and clinical scientists To speed progress, it seems prudent to bring basic and clinical vision scientists together to identify diseases and patient populations that are the easiest target for regenerative therapies. At the same time, scientists from diverse backgrounds (e.g., bioengineers, industry researchers, drug designers, anatomists, electrophysiologists, clinical ophthalmologists, etc.), need to collaborate rather than work in isolation, to speed translational research and development of candidate therapies that could be quickly tested in clinical trials. This would likely require innovative models to support these interdisciplinary studies.

If the field selects a priority clinical disorder or disease model, as has been done when addressing photoreceptor regeneration, the focused effort may speed development of clinically relevant therapies. Acute optic nerve injury is not very common clinically, so it may be prudent to think about how findings on the basics of regeneration might be applicable to slowing degenerative diseases, such as glaucoma or Leber's hereditary optic neuropathy. Optic nerve crush might have some relation to traumatic brain injury, but optic neuritis, a frequent manifestation of multiple sclerosis, affects a much wider population. Using optic neuritis (Aktas et al., 2016), stroke (Li et al., 2015), or some other more common (and treatable) model for regeneration studies could be especially useful.

Researchers have identified mitochondrial alterations in spinal cord lesions just after the axon is transected (Jia et al., 2016). If one could identify similar states in the optic nerve and gear therapies toward those, it might be possible to save the axon at an early stage of insult.

Ask patients what they consider meaningful improvements in visual function. Some measurable improvements might not seem meaningful to scientists, but could be welcomed by patients and vice versa. Image motion resulting from eye movements is likely important to vision. To what extent should we consider not just sensory, but also sensorimotor recovery? Researchers should think in terms of restoring human vision incrementally rather than aiming for perfect vision, and in that process of restoration, gain more understanding of how the human visual system works.

Brain/machine interface experiments have shown that relatively small numbers of neurons (a hundred or hundreds) are adequate to move cursors and robotic arms. Complementing at least partial regeneration with establishment of methods, such as 
microchips or implants, might provide a way to enhance functional recovery (Yan et al., 2016). Researchers using brainmachine interfaces to probe the plasticity of the motor cortex suggests that it is important to get targeting close and specific; the system is not infinitely plastic. Monkeys using a brain-machine interface to learn to control movement of a cursor can quickly adapt cortical activity to new mapping if a perturbation of mapping between the neural activity and motion of the cursor is small. But if the mapping is too perturbed, the monkey cannot adapt. Similar limitations probably apply to restoration of function in the visual system.

Many of the effective treatments to date in model systems are performed (or at least started) before the injury and prime RGCs to survive and regenerate their axons. For treatments to be meaningful at the clinical level, they need to be applied after the injury has occurred. Researchers should begin thinking about introduction of small molecules or use of noninvasive methods, such as visual therapy.

Amblyopia is a good system for studying plasticity and recovery from vision loss in humans. Researchers should take advantage of human genetics and genome-wide association studies (many are in progress) to gather information about genes implicated in amblyopia, and use this information to inform studies using model organisms (Vagge and Nelson, 2016).

Culturing and screening iPSC-derived human RGCs has the advantage of getting information from human cells, which would seem to be more directly relevant to developing regenerative therapies. These in vitro approaches may also cost much less than screening in mammals. However, studying cells in vitro, outside their normal environment, may not provide essential information about the spatial and temporal roles of different proteins that RGCs encounter at different times during regeneration. Moreover, ES cells may not possess the same directives for differentiation compared with immature RGCs or their precursors harvested in vivo (J. Goldberg, personal communication).

Geron conducted a safety study in 5 patients with spinal cord injury using human ES cell-derived oligodendrocyte progenitors. Another company (Asterias) obtained the intellectual property plans to launch a Phase $1 / 2$ a open-label, single-arm study testing escalating doses. Even with these developments, the field of regeneration lacks a positive control for testing agents that promote regeneration (such as fasodil, a commercially available Rho kinase inhibitor). A parallel approach in the field of cell and tissue engineering might accelerate progress if the work makes it possible to generate cells and transplant the axon itself.

Researchers should patent discoveries to help ensure interest of an industry partner. Some scientists do not recognize that having a patent on a discovery is often essential for commercialization. Barriers to patenting discoveries should be lowered, or alternative methods to bring discoveries to the clinic should be identified.

\section{Panelist predictions}

Panelists were asked to estimate a timeline for how long it will take to get functional recovery in humans. The comments included the following:

- Regeneration for photoreceptor degeneration diseases is more likely than reconnecting a transected optic nerve because it only requires connecting bipolar cells to photoreceptors that are saved or rescued through gene therapy or regenerated through stem cells.
- Recovery of simple visual function, such as detecting light, is feasible in a few years. Recovery of "real" function, such as form vision, is far away.

- Insights from regeneration research will help in finding ways to treat slowly progressive diseases. Restoring function in patients who lose RGC connections from a transection of the optic nerve may not be a realistic goal.

- Frank regeneration is likely "a bridge too far." More feasible within a relatively short time scale, such as $10-15$ years, are finding ways to stop further death of ganglion cells and promote plasticity in the target to restore function, via manipulating activity and/or genetic manipulation.

- Substantial regeneration of most ganglion cell types could be achieved in the mouse within 5 years; in human patients, in 10-15 years, through a combination of biology (stimulating axons to grow a short distance) and an engineered device that supplies factors to encourage growth through the optic chiasm to the dLGN.

- Restoring vision in humans is a different issue than regeneration and is unlikely to happen on a clinical level in the next two to three decades. It is more likely that there will be bigger advances initially with treating partial injuries, such as optic neuritis or glaucoma, to prevent degeneration and then enhance regeneration.

- Recent advances in spinal cord injury, applying epidural electrical stimulation and rehabilitation/training, have demonstrated that completely paralyzed patients can regain some function (Lu et al., 2016). This suggests that achieving clinical recovery in vision is likely through stimulation of some sort.

- Some panelists expressed skepticism about moving into the clinic within a short time frame, but said researchers and clinicians will gain a deeper knowledge about what is needed to implement regeneration by communicating with each other, starting in the present.

\section{Summary}

Despite the gaps in our knowledge and barriers to progress in promoting the restoration of visual system function following disease or trauma, new technical advances and a merger of basic science with clinical and translational efforts have the promise of succeeding in reconnecting RGCs to the brain. The usefulness of gathering together a diverse group of experts studying a range of model systems to think about the big issues in reconnecting neurons in the visual system rather than simply "working on our little islands" was substantial. It may not be possible to reconnect the visual system in a meaningful way in the very near future, but thinking collaboratively about the state of the field and identifying significant barriers to progress, which we have summarized here, will accelerate fundamental advances in both basic and clinical arenas that would not otherwise occur. Hopefully, this will hasten the day when viable treatments for restoring visual function can be provided to patients suffering from vision loss.

\section{References}

Aktas O, Albrecht P, Hartung HP (2016) Optic neuritis as a phase 2 paradigm for neuroprotection therapies of multiple sclerosis: update on current trials and perspectives. Curr Opin Neurol 29:199-204. CrossRef Medline

Amamoto R, Huerta VG, Takahashi E, Dai G, Grant AK, Fu Z, Arlotta P (2016) Adult axolotls can regenerate original neuronal diversity in response to brain injury. Elife 5:e13998. CrossRef Medline

Anderson MA, Burda JE, Ren Y, Ao Y, O’Shea TM, Kawaguchi R, Coppola G, 
Khakh BS, Deming TJ, Sofroniew MV (2016) Astrocyte scar formation aids central nervous system axon regeneration. Nature 532:195-200. CrossRef Medline

Araki M (2014) A novel mode of retinal regeneration: the merit of a new Xenopus model. Neural Regen Res 9:2125-2127. CrossRef Medline

Atwal JK, Pinkston-Gosse J, Syken J, Stawicki S, Wu Y, Shatz C, TessierLavigne M (2008) PirB is a functional receptor for myelin inhibitors of axonal regeneration. Science 322:967-970. CrossRef Medline

Baden T, Berens P, Franke K, Román Rosón M, Bethge M, Euler T (2016) The functional diversity of retinal ganglion cells in the mouse. Nature 529:345-350. CrossRef Medline

Baier H (2013) Synaptic laminae in the visual system: molecular mechanisms forming layers of perception. Annu Rev Cell Dev Biol 29:385-416. CrossRef Medline

Balasubramanian R, Bui A, Ding Q, Gan L (2014) Expression of LIMhomeodomain transcription factors in the developing and mature mouse retina. Gene Expr Patterns 14:1-8. CrossRef Medline

Baldwin KT, Carbajal KS, Segal BM, Giger RJ (2015) Neuroinflammation triggered by beta-glucan/dectin-1 signaling enables CNS axon regeneration. Proc Natl Acad Sci U S A 112:2581-2586. CrossRef Medline

Balmer TS, Pallas SL (2015) Refinement but not maintenance of visual receptive fields is independent of visual experience. Cereb Cortex 25: 904-917. CrossRef Medline

Basso DM, Beattie MS, Bresnahan JC (1995) A sensitive and reliable locomotor rating scale for open field testing in rats. J Neurotrauma 12:1-21. CrossRef Medline

Basso DM, Fisher LC, Anderson AJ, Jakeman LB, McTigue DM, Popovich PG (2006) Basso Mouse Scale for locomotion detects differences in recovery after spinal cord injury in five common mouse strains. J Neurotrauma 23:635-659. CrossRef Medline

Beazley LD, Rodger J, Chen P, Tee LB, Stirling RV, Taylor AL, Dunlop SA (2003) Training on a visual task improves the outcome of optic nerve regeneration. J Neurotrauma 20:1263-1270. CrossRef Medline

Becker CG, Becker T (2015) Neuronal regeneration from ependymo-radial glial cells: cook, little pot, cook! Dev Cell 32:516-527. CrossRef Medline

Bei F, Lee HH, Liu X, Gunner G, Jin H, Ma L, Wang C, Hou L, Hensch TK, Frank E, Sanes JR, Chen C, Fagiolini M, He Z (2016) Restoration of visual function by enhancing conduction in regenerated axons. Cell 164: 219-232. CrossRef Medline

Bennett ML, Bennett FC, Liddelow SA, Ajami B, Zamanian JL, Fernhoff NB, Mulinyawe SB, Bohlen CJ, Adil A, Tucker A, Weissman IL, Chang EF, Li G, Grant GA, Hayden Gephart MG, Barres BA (2016) New tools for studying microglia in the mouse and human CNS. Proc Natl Acad Sci U S A 113:E1738-E1746. CrossRef Medline

Benowitz LI, He Z, Goldberg JL (2015) Reaching the brain: advances in optic nerve regeneration. Exp Neurol. Advance online publication. Retrieved Dec. 31, 2015. doi: 10.1016/j.expneurol.2015.12.015. CrossRef Medline

Berardi N, Maffei L (1999) From visual experience to visual function: roles of neurotrophins. J Neurobiol 41:119-126. CrossRef Medline

Blackmore MG, Wang Z, Lerch JK, Motti D, Zhang YP, Shields CB, Lee JK, Goldberg JL, Lemmon VP, Bixby JL (2012) Kruppel-like Factor 7 engineered for transcriptional activation promotes axon regeneration in the adult corticospinal tract. Proc Natl Acad Sci U S A 109:7517-7522. CrossRef Medline

Bochner DN, Sapp RW, Adelson JD, Zhang S, Lee H, Djurisic M, Syken J, Dan Y, Shatz CJ (2014) Blocking PirB up-regulates spines and functional synapses to unlock visual cortical plasticity and facilitate recovery from amblyopia. Sci Transl Med 6:258ra140. CrossRef Medline

Brace EJ, Wu C, Valakh V, DiAntonio A (2014) SkpA restrains synaptic terminal growth during development and promotes axonal degeneration following injury. J Neurosci 34:8398-8410. CrossRef Medline

Bradke F, Fawcett JW, Spira ME (2012) Assembly of a new growth cone after axotomy: the precursor to axon regeneration. Nat Rev Neurosci 13:183193. CrossRef Medline

Bregman BS, Kunkel-Bagden E, Schnell L, Dai HN, Gao D, Schwab ME (1995) Recovery from spinal cord injury mediated by antibodies to neurite growth inhibitors. Nature 378:498-501. CrossRef Medline

Brittis PA, Silver J (1995) Multiple factors govern intraretinal axon guidance: a time-lapse study. Mol Cell Neurosci 6:413-432. CrossRef Medline

Bryson JB, Machado CB, Crossley M, Stevenson D, Bros-Facer V, Burrone J, Greensmith L, Lieberam I (2014) Optical control of muscle function by transplantation of stem cell-derived motor neurons in mice. Science 344: 94-97. CrossRef Medline

Byrne AB, Edwards TJ, Hammarlund M (2011) In vivo laser axotomy in C. elegans. J Vis Exp 51:2707. CrossRef Medline

Callahan A, Abeyruwan SW, Al-Ali H, Sakurai K, Ferguson AR, Popovich PG, Shah NH, Visser U, Bixby JL, Lemmon VP (2016) RegenBase: a knowledge base of spinal cord injury biology for translational research. Database (Oxford) 2016.

Cattin AL, Burden JJ, Van Emmenis L, Mackenzie FE, Hoving JJ, Garcia Calavia N, Guo Y, McLaughlin M, Rosenberg LH, Quereda V, Jamecna D, Napoli I, Parrinello S, Enver T, Ruhrberg C, Lloyd AC (2015) Macrophage-induced blood vessels guide Schwann cell-mediated regeneration of peripheral nerves. Cell 162:1127-1139. CrossRef Medline

Chan SO, Guillery RW (1994) Changes in fiber order in the optic nerve and tract of rat embryos. J Comp Neurol 344:20-32. CrossRef Medline

Chandran V, Coppola G, Nawabi H, Omura T, Versano R, Huebner EA, Zhang A, Costigan M, Yekkirala A, Barrett L, Blesch A, Michaelevski I, Davis-Turak J, Gao F, Langfelder P, Horvath S, He Z, Benowitz L, Fainzilber M, Tuszynski M, et al. (2016) A systems-level analysis of the peripheral nerve intrinsic axonal growth program. Neuron 89:956-970. CrossRef Medline

Chang WC, Hawkes E, Keller CG, Sretavan DW (2010) Axon repair: surgical application at a subcellular scale. Wiley Interdiscip Rev Nanomed Nanobiotechnol 2:151-161. CrossRef Medline

Chen L, Liu Z, Zhou B, Wei C, Zhou Y, Rosenfeld MG, Fu XD, Chisholm AD, Jin Y (2016) CELF RNA binding proteins promote axon regeneration in C. elegans and mammals through alternative splicing of Syntaxins. Elife 5:e16072. CrossRef Medline

Chen SK, Badea TC, Hattar S (2011) Photoentrainment and pupillary light reflex are mediated by distinct populations of ipRGCs. Nature 476:92-95. CrossRef Medline

Davis MF, Figueroa Velez DX, Guevarra RP, Yang MC, Habeeb M, Carathedathu MC, Gandhi SP (2015) Inhibitory neuron transplantation into adult visual cortex creates a new critical period that rescues impaired vision. Neuron 86:1055-1066. CrossRef Medline

de Lima S, Koriyama Y, Kurimoto T, Oliveira JT, Yin Y, Li Y, Gilbert HY, Fagiolini M, Martinez AM, Benowitz L (2012) Full-length axon regeneration in the adult mouse optic nerve and partial recovery of simple visual behaviors. Proc Natl Acad Sci U S A 109:9149-9154. CrossRef Medline

Dell AL, Fried-Cassorla E, Xu H, Raper JA (2013) cAMP-induced expression of neuropilin 1 promotes retinal axon crossing in the zebrafish optic chiasm. J Neurosci 33:11076-11088. CrossRef Medline

Delloye-Bourgeois C, Jacquier A, Falk J, Castellani V (2014) Use of pHluorin to assess the dynamics of axon guidance receptors in cell culture and in the chick embryo. J Vis Exp:e50883. CrossRef Medline

Dhande OS, Huberman AD (2014) Visual circuits: mouse retina no longer a level playing field. Curr Biol 24:R155-R156. CrossRef Medline

Diekmann H, Leibinger M, Fischer D (2013) Do growth-stimulated retinal ganglion cell axons find their central targets after optic nerve injury? New insights by three-dimensional imaging of the visual pathway. Exp Neurol 248:254-257. CrossRef Medline

Dilger EK, Krahe TE, Morhardt DR, Seabrook TA, Shin HS, Guido W (2015) Absence of plateau potentials in dLGN cells leads to a breakdown in retinogeniculate refinement. J Neurosci 35:3652-3662. CrossRef Medline

Dräger UC (1985) Birth dates of retinal ganglion cells giving rise to the crossed and uncrossed optic projections in the mouse. Proc R Soc Lond B Biol Sci 224:57-77. CrossRef Medline

Duan X, Qiao M, Bei F, Kim IJ, He Z, Sanes JR (2015) Subtype-specific regeneration of retinal ganglion cells following axotomy: effects of osteopontin and mTOR signaling. Neuron 85:1244-1256. CrossRef Medline

El-Danaf RN, Krahe TE, Dilger EK, Bickford ME, Fox MA, Guido W (2015) Developmental remodeling of relay cells in the dorsal lateral geniculate nucleus in the absence of retinal input. Neural Dev 10:19. CrossRef Medline

Elsaeidi F, Bemben MA, Zhao XF, Goldman D (2014) Jak/Stat signaling stimulates zebrafish optic nerve regeneration and overcomes the inhibitory actions of Socs3 and Sfpq. J Neurosci 34:2632-2644. CrossRef Medline

Endo M, Hattori M, Toriyabe H, Ohno H, Kamiguchi H, Iino Y, Ozawa T 
(2016) Optogenetic activation of axon guidance receptors controls direction of neurite outgrowth. Sci Rep 6:23976. CrossRef Medline

Enes J, Langwieser N, Ruschel J, Carballosa-Gonzalez MM, Klug A, Traut MH, Ylera B, Tahirovic S, Hofmann F, Stein V, Moosmang S, Hentall ID, Bradke F (2010) Electrical activity suppresses axon growth through $\mathrm{Ca}(\mathrm{v}) 1.2$ channels in adult primary sensory neurons. Curr Biol 20:11541164. CrossRef Medline

Erskine L, Reijntjes S, Pratt T, Denti L, Schwarz Q, Vieira JM, Alakakone B, Shewan D, Ruhrberg C (2011) VEGF signaling through neuropilin 1 guides commissural axon crossing at the optic chiasm. Neuron 70 : 951-965. CrossRef Medline

Espinosa JS, Stryker MP (2012) Development and plasticity of the primary visual cortex. Neuron 75:230-249. CrossRef Medline

Fabre PJ, Shimogori T, Charron F (2010) Segregation of ipsilateral retinal ganglion cell axons at the optic chiasm requires the Shh receptor Boc. J Neurosci 30:266-275. CrossRef Medline

Fagiolini M, Hensch TK (2000) Inhibitory threshold for critical-period activation in primary visual cortex. Nature 404:183-186. CrossRef Medline

Fraser SE, O'Rourke NA (1990) In situ analysis of neuronal dynamics and positional cues in the patterning of nerve connections. J Exp Biol 153:6170. Medline

Fu QL, Liao XX, Li X, Chen D, Shi J, Wen W, Lee DH, So KF (2011) Soluble Nogo-66 receptor prevents synaptic dysfunction and rescues retinal ganglion cell loss in chronic glaucoma. Invest Ophthalmol Vis Sci 52:83748380. CrossRef Medline

Furman M, Xu HP, Crair MC (2013) Competition driven by retinal waves promotes morphological and functional synaptic development of neurons in the superior colliculus. J Neurophysiol 110:1441-1454. CrossRef Medline

Gallo V, Deneen B (2014) Glial development: the crossroads of regeneration and repair in the CNS. Neuron 83:283-308. CrossRef Medline

García-Frigola C, Herrera E (2010) Zic2 regulates the expression of Sert to modulate eye-specific refinement at the visual targets. EMBO J 29:31703183. CrossRef Medline

Gerdts J, Brace EJ, Sasaki Y, DiAntonio A, Milbrandt J (2015) SARM1 activation triggers axon degeneration locally via $\mathrm{NAD}(+)$ destruction. Science 348:453-457. CrossRef Medline

Godement P, Salaün J, Imbert M (1984) Prenatal and postnatal development of retinogeniculate and retinocollicular projections in the mouse. J Comp Neurol 230:552-575. CrossRef Medline

Godement P, Wang LC, Mason CA (1994) Retinal axon divergence in the optic chiasm: dynamics of growth cone behavior at the midline. J Neurosci 14:7024-7039. Medline

Goldman D (2014) Muller glial cell reprogramming and retina regeneration. Nat Rev Neurosci 15:431-442. CrossRef Medline

Göritz C, Dias DO, Tomilin N, Barbacid M, Shupliakov O, Frisén J (2011) A pericyte origin of spinal cord scar tissue. Science 333:238-242. CrossRef Medline

Guillery RW, Walsh C (1987) Changing glial organization relates to changing fiber order in the developing optic nerve of ferrets. J Comp Neurol 265:203-217. CrossRef Medline

Guy AT, Nagatsuka Y, Ooashi N, Inoue M, Nakata A, Greimel P, Inoue A, Nabetani T, Murayama A, Ohta K, Ito Y, Aoki J, Hirabayashi Y, Kamiguchi H (2015) NEURONAL DEVELOPMENT: glycerophospholipid regulation of modality-specific sensory axon guidance in the spinal cord. Science 349:974-977. CrossRef Medline

Hamid S, Hayek R (2008) Role of electrical stimulation for rehabilitation and regeneration after spinal cord injury: an overview. Eur Spine J 17: 1256-1269. CrossRef Medline

Hammarlund M, Jin Y (2014) Axon regeneration in C. elegans. Curr Opin Neurobiol 27:199-207. CrossRef Medline

Harris WA, Holt CE, Bonhoeffer F (1987) Retinal axons with and without their somata, growing to and arborizing in the tectum of Xenopus embryos: a time-lapse video study of single fibres in vivo. Development 101:123-133. Medline

He HY, Ray B, Dennis K, Quinlan EM (2007) Experience-dependent recovery of vision following chronic deprivation amblyopia. Nat Neurosci 10: 1134-1136. CrossRef Medline

He Z, Jin Y (2016) Intrinsic control of axon regeneration. Neuron 90:437451. CrossRef Medline

Herrera E, Brown L, Aruga J, Rachel RA, Dolen G, Mikoshiba K, Brown S,
Mason CA (2003) Zic2 patterns binocular vision by specifying the uncrossed retinal projection. Cell 114:545-557. CrossRef Medline

Hong S, Dissing-Olesen L, Stevens B (2016) New insights on the role of microglia in synaptic pruning in health and disease. Curr Opin Neurobiol 36:128-134. CrossRef Medline

Hong YK, Chen C (2011) Wiring and rewiring of the retinogeniculate synapse. Curr Opin Neurobiol 21:228-237. CrossRef Medline

Hong YK, Park S, Litvina EY, Morales J, Sanes JR, Chen C (2014) Refinement of the retinogeniculate synapse by bouton clustering. Neuron 84: 332-339. CrossRef Medline

Hooks BM, Chen C (2006) Distinct roles for spontaneous and visual activity in remodeling of the retinogeniculate synapse. Neuron 52:281-291. CrossRef Medline

Hooks BM, Chen C (2007) Critical periods in the visual system: changing views for a model of experience-dependent plasticity. Neuron 56:312326. CrossRef Medline

Hooks BM, Chen C (2008) Vision triggers an experience-dependent sensitive period at the retinogeniculate synapse. J Neurosci 28:4807-4817. CrossRef Medline

Höpker VH, Shewan D, Tessier-Lavigne M, Poo M, Holt C (1999) Growthcone attraction to netrin-1 is converted to repulsion by laminin-1. Nature 401:69-73. CrossRef Medline

Hughes EG, Kang SH, Fukaya M, Bergles DE (2013) Oligodendrocyte progenitors balance growth with self-repulsion to achieve homeostasis in the adult brain. Nat Neurosci 16:668-676. CrossRef Medline

Imai T, Yamazaki T, Kobayakawa R, Kobayakawa K, Abe T, Suzuki M, Sakano H (2009) Pre-target axon sorting establishes the neural map topography. Science 325:585-590. CrossRef Medline

Isaacman-Beck J, Schneider V, Franzini-Armstrong C, Granato M (2015) The lh3 glycosyltransferase directs target-selective peripheral nerve regeneration. Neuron 88:691-703. CrossRef Medline

Jaubert-Miazza L, Green E, Lo FS, Bui K, Mills J, Guido W (2005) Structural and functional composition of the developing retinogeniculate pathway in the mouse. Vis Neurosci 22:661-676. CrossRef Medline

Jaworski A, Tom I, Tong RK, Gildea HK, Koch AW, Gonzalez LC, TessierLavigne M (2015) Operational redundancy in axon guidance through the multifunctional receptor Robo3 and its ligand NELL2. Science 350: 961-965. CrossRef Medline

Jia ZQ, Li G, Zhang ZY, Li HT, Wang JQ, Fan ZK, Lv G (2016) Time representation of mitochondrial morphology and function after acute spinal cord injury. Neural Regen Res 11:137-143. CrossRef Medline

Jin K, Xiao D, Andersen B, Xiang M (2016) Lmo4 and other LIM domain only factors are necessary and sufficient for multiple retinal cell type development. Dev Neurobiol 76:900-915. CrossRef Medline

Jin X, Yamashita T (2016) Microglia in central nervous system repair after injury. J Biochem 159:491-496. CrossRef Medline

Kalia A, Lesmes LA, Dorr M, Gandhi T, Chatterjee G, Ganesh S, Bex PJ, Sinha P (2014) Development of pattern vision following early and extended blindness. Proc Natl Acad Sci U S A 111:2035-2039. CrossRef Medline

Kalil K, Skene JH (1986) Elevated synthesis of an axonally transported protein correlates with axon outgrowth in normal and injured pyramidal tracts. J Neurosci 6:2563-2570. Medline

Kaneko M, Stryker MP (2014) Sensory experience during locomotion promotes recovery of function in adult visual cortex. Elife 3:e02798. CrossRef Medline

Kay JN, De la Huerta I, Kim IJ, Zhang Y, Yamagata M, Chu MW, Meister M, Sanes JR (2011) Retinal ganglion cells with distinct directional preferences differ in molecular identity, structure, and central projections. J Neurosci 31:7753-7762. CrossRef Medline

Kim IJ, Zhang Y, Yamagata M, Meister M, Sanes JR (2008) Molecular identification of a retinal cell type that responds to upward motion. Nature 452:478-482. CrossRef Medline

King C, Lacey R, Rodger J, Bartlett C, Dunlop S, Beazley L (2004) Characterisation of tectal ephrin-A2 expression during optic nerve regeneration in goldfish: implications for restoration of topography. Exp Neurol 187: 380-387. CrossRef Medline

Kobayashi Y, Ye Z, Hensch TK (2015) Clock genes control cortical critical period timing. Neuron 86:264-275. CrossRef Medline

Kurimoto T, Yin Y, Habboub G, Gilbert HY, Li Y, Nakao S, HafeziMoghadam A, Benowitz LI (2013) Neutrophils express oncomodulin and promote optic nerve regeneration. J Neurosci 33:14816-14824. CrossRef Medline 
Kurup N, Yan D, Goncharov A, Jin Y (2015) Dynamic microtubules drive circuit rewiring in the absence of neurite remodeling. Curr Biol 25:15941605. CrossRef Medline

Kuwajima T, Yoshida Y, Takegahara N, Petros TJ, Kumanogoh A, Jessell TM, Sakurai T, Mason C (2012) Optic chiasm presentation of Semaphorin6D in the context of Plexin-A1 and Nr-CAM promotes retinal axon midline crossing. Neuron 74:676-690. CrossRef Medline

Lee H, Brott BK, Kirkby LA, Adelson JD, Cheng S, Feller MB, Datwani A, Shatz CJ (2014) Synapse elimination and learning rules co-regulated by MHC class I H2-Db. Nature 509:195-200. CrossRef Medline

LeGates TA, Altimus CM, Wang H, Lee HK, Yang S, Zhao H, Kirkwood A, Weber ET, Hattar S (2012) Aberrant light directly impairs mood and learning through melanopsin-expressing neurons. Nature 491:594-598. CrossRef Medline

LeGates TA, Fernandez DC, Hattar S (2014) Light as a central modulator of circadian rhythms, sleep and affect. Nat Rev Neurosci 15:443-454. CrossRef Medline

Li H, Kuwajima T, Oakley D, Nikulina E, Hou J, Yang WS, Lowry ER, Lamas NJ, Amoroso MW, Croft GF, Hosur R, Wichterle H, Sebti S, Filbin MT, Stockwell B, Henderson CE (2016) Protein prenylation constitutes an endogenous brake on axonal growth. Cell Rep 16:545-558. CrossRef Medline

Li RW, Ngo C, Nguyen J, Levi DM (2011) Video-game play induces plasticity in the visual system of adults with amblyopia. PLoS Biol 9:e1001135. CrossRef Medline

Li S, Nie EH, Yin Y, Benowitz LI, Tung S, Vinters HV, Bahjat FR, StenzelPoore MP, Kawaguchi R, Coppola G, Carmichael ST (2015) GDF10 is a signal for axonal sprouting and functional recovery after stroke. Nat Neurosci 18:1737-1745. CrossRef Medline

Li Y, Field PM, Raisman G (1997) Repair of adult rat corticospinal tract by transplants of olfactory ensheathing cells. Science 277:2000-2002. CrossRef Medline

Lim JH, Stafford BK, Nguyen PL, Lien BV, Wang C, Zukor K, He Z, Huberman AD (2016) Neural activity promotes long-distance, target-specific regeneration of adult retinal axons. Nat Neurosci 19:1073-1084. CrossRef Medline

Lindwall C, Fothergill T, Richards LJ (2007) Commissure formation in the mammalian forebrain. Curr Opin Neurobiol 17:3-14. CrossRef Medline

Liu K, Tedeschi A, Park KK, He Z (2011) Neuronal intrinsic mechanisms of axon regeneration. Annu Rev Neurosci 34:131-152. CrossRef Medline

Lodato S, Arlotta P (2015) Generating neuronal diversity in the mammalian cerebral cortex. Annu Rev Cell Dev Biol 31:699-720. CrossRef Medline

Lom B, Cohen-Cory S (1999) Brain-derived neurotrophic factor differentially regulates retinal ganglion cell dendritic and axonal arborization in vivo. J Neurosci 19:9928-9938. Medline

Lorenzana AO, Lee JK, Mui M, Chang A, Zheng B (2015) A surviving intact branch stabilizes remaining axon architecture after injury as revealed by in vivo imaging in the mouse spinal cord. Neuron 86:947-954. CrossRef Medline

Lu DC, Edgerton VR, Modaber M, AuYong N, Morikawa E, Zdunowski S, Sarino ME, Sarrafzadeh M, Nuwer MR, Roy RR, Gerasimenko Y (2016) Engaging cervical spinal cord networks to reenable volitional control of hand function in tetraplegic patients. Neurorehabil Neural Repair. Advance online publication. Retrieved Dec. 31, 2015. doi: 10.1177/ 1545968316644344. CrossRef Medline

Luo L, Flanagan JG (2007) Development of continuous and discrete neural maps. Neuron 56:284-300. CrossRef Medline

Luo X, Salgueiro Y, Beckerman SR, Lemmon VP, Tsoulfas P, Park KK (2013) Three-dimensional evaluation of retinal ganglion cell axon regeneration and pathfinding in whole mouse tissue after injury. Exp Neurol 247:653662. CrossRef Medline

Luo X, Ribeiro M, Bray ER, Lee DH, Yungher BJ, Mehta ST, Thakor KA, Diaz F, Lee JK, Moraes CT, Bixby JL, Lemmon VP, Park KK (2016) Enhanced transcriptional activity and mitochondrial localization of STAT3 coinduce axon regrowth in the adult central nervous system. Cell Rep 15: 398-410. CrossRef Medline

Macosko EZ, Basu A, Satija R, Nemesh J, Shekhar K, Goldman M, Tirosh I, Bialas AR, Kamitaki N, Martersteck EM, Trombetta JJ, Weitz DA, Sanes JR, Shalek AK, Regev A, McCarroll SA (2015) Highly parallel genomewide expression profiling of individual cells using nanoliter droplets. Cell 161:1202-1214. CrossRef Medline

Mason CA, Sretavan DW (1997) Glia, neurons, and axon pathfinding during optic chiasm development. Curr Opin Neurobiol 7:647-653. CrossRef Medline

Mason CA, Kuwajima T, Wang Q (2014) The development of retinal decussations. In: The visual neurosciences (Chalupa LM, Werner JS, eds), pp 1317-1334. Cambridge, MA: Massachusetts Institute of Technology.

McGee AW, Yang Y, Fischer QS, Daw NW, Strittmatter SM (2005) Experience-driven plasticity of visual cortex limited by myelin and Nogo receptor. Science 309:2222-2226. CrossRef Medline

Moore DL, Blackmore MG, Hu Y, Kaestner KH, Bixby JL, Lemmon VP, Goldberg JL (2009) KLF family members regulate intrinsic axon regeneration ability. Science 326:298-301. CrossRef Medline

Nahmani M, Turrigiano GG (2014) Adult cortical plasticity following injury: recapitulation of critical period mechanisms? Neuroscience 283:416. CrossRef Medline

Nakagawa S, Brennan C, Johnson KG, Shewan D, Harris WA, Holt CE (2000) Ephrin-B regulates the Ipsilateral routing of retinal axons at the optic chiasm. Neuron 25:599-610. CrossRef Medline

Nakano T, Ando S, Takata N, Kawada M, Muguruma K, Sekiguchi K, Saito K, Yonemura S, Eiraku M, Sasai Y (2012) Self-formation of optic cups and storable stratified neural retina from human ESCs. Cell Stem Cell 10: 771-785. CrossRef Medline

Nawabi H, Belin S, Cartoni R, Williams PR, Wang C, Latremolière A, Wang X, Zhu J, Taub DG, Fu X, Yu B, Gu X, Woolf CJ, Liu JS, Gabel CV, Steen JA, He Z (2015) Doublecortin-like kinases promote neuronal survival and induce growth cone reformation via distinct mechanisms. Neuron 88 : 704-719. CrossRef Medline

Neves J, Zhu J, Sousa-Victor P, Konjikusic M, Riley R, Chew S, Qi Y, Jasper H, Lamba DA (2016) Immune modulation by MANF promotes tissue repair and regenerative success in the retina. Science 353:aaf3646. CrossRef Medline

Niemi JP, DeFrancesco-Lisowitz A, Cregg JM, Howarth M, Zigmond RE (2016) Overexpression of the monocyte chemokine CCL2 in dorsal root ganglion neurons causes a conditioning-like increase in neurite outgrowth and does so via a STAT3 dependent mechanism. Exp Neurol 275:25-37. CrossRef Medline

Nikolaou N, Meyer MP (2015) Lamination speeds the functional development of visual circuits. Neuron 88:999-1013. CrossRef Medline

Nishiyama A, Suzuki R, Zhu X (2014) NG2 cells (polydendrocytes) in brain physiology and repair. Front Neurosci 8:133. CrossRef Medline

Nix P, Hammarlund M, Hauth L, Lachnit M, Jorgensen EM, Bastiani M (2014) Axon regeneration genes identified by RNAi screening in $C$. elegans. J Neurosci 34:629-645. CrossRef Medline

Omura T, Omura K, Tedeschi A, Riva P, Painter MW, Rojas L, Martin J, Lisi V, Huebner EA, Latremoliere A, Yin Y, Barrett LB, Singh B, Lee S, Crisman T, Gao F, Li S, Kapur K, Geschwind DH, Kosik KS, et al. (2015) Robust axonal regeneration occurs in the injured CAST/Ei mouse CNS. Neuron 86:1215-1227. CrossRef Medline

Osterhout JA, Josten N, Yamada J, Pan F, Wu SW, Nguyen PL, Panagiotakos G, Inoue YU, Egusa SF, Volgyi B, Inoue T, Bloomfield SA, Barres BA, Berson DM, Feldheim DA, Huberman AD (2011) Cadherin-6 mediates axon-target matching in a non-image-forming visual circuit. Neuron 71: 632-639. CrossRef Medline

Osterhout JA, El-Danaf RN, Nguyen PL, Huberman AD (2014) Birthdate and outgrowth timing predict cellular mechanisms of axon target matching in the developing visual pathway. Cell Rep 8:1006-1017. CrossRef Medline

Osterhout JA, Stafford BK, Nguyen PL, Yoshihara Y, Huberman AD (2015) Contactin-4 mediates axon-target specificity and functional development of the accessory optic system. Neuron 86:985-999. CrossRef Medline

Özel MN, Langen M, Hassan BA, Hiesinger PR (2015) Filopodial dynamics and growth cone stabilization in Drosophila visual circuit development. Elife 4:e10721. CrossRef Medline

Pak W, Hindges R, Lim YS, Pfaff SL, O’Leary DD (2004) Magnitude of binocular vision controlled by islet-2 repression of a genetic program that specifies laterality of retinal axon pathfinding. Cell 119:567-578. CrossRef Medline

Parrinello S, Napoli I, Ribeiro S, Wingfield Digby P, Fedorova M, Parkinson DB, Doddrell RD, Nakayama M, Adams RH, Lloyd AC (2010) EphB signaling directs peripheral nerve regeneration through Sox2-dependent Schwann cell sorting. Cell 143:145-155. CrossRef Medline

Peng S, Shi Z, Su H, So KF, Cui Q (2016) Increased production of omega-3 
fatty acids protects retinal ganglion cells after optic nerve injury in mice. Exp Eye Res 148:90-96. CrossRef Medline

Pizzorusso T, Medini P, Berardi N, Chierzi S, Fawcett JW, Maffei L (2002) Reactivation of ocular dominance plasticity in the adult visual cortex. Science 298:1248-1251. CrossRef Medline

Plas DT, Lopez JE, Crair MC (2005) Pretarget sorting of retinocollicular axons in the mouse. J Comp Neurol 491:305-319. CrossRef Medline

Poliak S, Norovich AL, Yamagata M, Sanes JR, Jessell TM (2016) Muscletype identity of proprioceptors specified by spatially restricted signals from limb mesenchyme. Cell 164:512-525. CrossRef Medline

Prins D, Hanekamp S, Cornelissen FW (2016) Structural brain MRI studies in eye diseases: are they clinically relevant? A review of current findings. Acta Ophthalmol 94:113-121. CrossRef Medline

Prusky GT, Alam NM, Beekman S, Douglas RM (2004) Rapid quantification of adult and developing mouse spatial vision using a virtual optomotor system. Invest Ophthalmol Vis Sci 45:4611-4616. CrossRef Medline

Reichman S, Terray A, Slembrouck A, Nanteau C, Orieux G, Habeler W, Nandrot EF, Sahel JA, Monville C, Goureau O (2014) From confluent human iPS cells to self-forming neural retina and retinal pigmented epithelium. Proc Natl Acad Sci U S A 111:8518-8523. CrossRef Medline

Richardson DS, Lichtman JW (2015) Clarifying tissue clearing. Cell 162: 246-257. CrossRef Medline

Rishal I, Fainzilber M (2014) Axon-soma communication in neuronal injury. Nat Rev Neurosci 15:32-42. CrossRef Medline

Robles E, Laurell E, Baier H (2014) The retinal projectome reveals brainarea-specific visual representations generated by ganglion cell diversity. Curr Biol 24:2085-2096. CrossRef Medline

Rodger J, Lindsey KA, Leaver SG, King CE, Dunlop SA, Beazley LD (2001) Expression of ephrin-A2 in the superior colliculus and EphA5 in the retina following optic nerve section in adult rat. Eur J Neurosci 14:19291936. CrossRef Medline

Rodger J, Vitale PN, Tee LB, King CE, Bartlett CA, Fall A, Brennan C, O'Shea JE, Dunlop SA, Beazley LD (2004) EphA/ephrin-A interactions during optic nerve regeneration: restoration of topography and regulation of ephrin-A2 expression. Mol Cell Neurosci 25:56-68. CrossRef Medline

Rousso DL, Qiao M, Kagan RD, Yamagata M, Palmiter RD, Sanes JR (2016) Two pairs of ON and OFF retinal ganglion cells are defined by intersectional patterns of transcription factor expression. Cell Rep 15:1930-1944. CrossRef Medline

Ruschel J, Hellal F, Flynn KC, Dupraz S, Elliott DA, Tedeschi A, Bates M, Sliwinski C, Brook G, Dobrindt K, Peitz M, Brüstle O, Norenberg MD, Blesch A, Weidner N, Bunge MB, Bixby JL, Bradke F (2015) Axonal regeneration: systemic administration of epothilone B promotes axon regeneration after spinal cord injury. Science 348:347-352. CrossRef Medline

Ruthazer ES, Aizenman CD (2010) Learning to see: patterned visual activity and the development of visual function. Trends Neurosci 33:183-192. CrossRef Medline

Ruthazer ES, Cline HT (2004) Insights into activity-dependent map formation from the retinotectal system: a middle-of-the-brain perspective. J Neurobiol 59:134-146. CrossRef Medline

Sakai JA, Halloran MC (2006) Semaphorin 3d guides laterality of retinal ganglion cell projections in zebrafish. Development 133:1035-1044. CrossRef Medline

Sánchez-Arrones L, Nieto-Lopez F, Sánchez-Camacho C, Carreres MI, Herrera E, Okada A, Bovolenta P (2013) Shh/Boc signaling is required for sustained generation of ipsilateral projecting ganglion cells in the mouse retina. J Neurosci 33:8596-8607. CrossRef Medline

Sánchez-Camacho C, Bovolenta P (2008) Autonomous and non-autonomous Shh signalling mediate the in vivo growth and guidance of mouse retinal ganglion cell axons. Development 135:3531-3541. CrossRef Medline

Sanes JR, Masland RH (2015) The types of retinal ganglion cells: current status and implications for neuronal classification. Annu Rev Neurosci 38:221-246. CrossRef Medline

Schmidt TM, Alam NM, Chen S, Kofuji P, Li W, Prusky GT, Hattar S (2014) A role for melanopsin in alpha retinal ganglion cells and contrast detection. Neuron 82:781-788. CrossRef Medline

Schwab ME, Bartholdi D (1996) Degeneration and regeneration of axons in the lesioned spinal cord. Physiol Rev 76:319-370. Medline

Schwab ME, Strittmatter SM (2014) Nogo limits neural plasticity and recovery from injury. Curr Opin Neurobiol 27:53-60. CrossRef Medline

Shah RD, Crair MC (2008) Retinocollicular synapse maturation and plas- ticity are regulated by correlated retinal waves. J Neurosci 28:292-303. CrossRef Medline

Shanks JA, Ito S, Schaevitz L, Yamada J, Chen B, Litke A, Feldheim DA (2016) Corticothalamic axons are essential for retinal ganglion cell axon targeting to the mouse dorsal lateral geniculate nucleus. J Neurosci 36: 5252-5263. CrossRef Medline

Shi M, Kumar SR, Motajo O, Kretschmer F, Mu X, Badea TC (2013) Genetic interactions between $\operatorname{Brn} 3$ transcription factors in retinal ganglion cell type specification. PLoS One 8:e76347. CrossRef Medline

Shigeoka T, Jung H, Jung J, Turner-Bridger B, Ohk J, Lin JQ, Amieux PS, Holt CE (2016) Dynamic axonal translation in developing and mature visual circuits. Cell 166:181-192. CrossRef Medline

Shirkey NJ, Manitt C, Zuniga L, Cohen-Cory S (2012) Dynamic responses of Xenopus retinal ganglion cell axon growth cones to netrin-1 as they innervate their in vivo target. Dev Neurobiol 72:628-648. CrossRef Medline

Silver J, Schwab ME, Popovich PG (2015) Central nervous system regenerative failure: role of oligodendrocytes, astrocytes, and microglia. Cold Spring Harb Perspect Biol 7:a020602. CrossRef Medline

Smith PD, Sun F, Park KK, Cai B, Wang C, Kuwako K, Martinez-Carrasco I, Connolly L, He Z (2009) SOCS3 deletion promotes optic nerve regeneration in vivo. Neuron 64:617-623. CrossRef Medline

Sofroniew MV (2015) Astrogliosis. Cold Spring Harb Perspect Biol 7:a020420. CrossRef Medline

Song Y, Sretavan D, Salegio EA, Berg J, Huang X, Cheng T, Xiong X, Meltzer S, Han C, Nguyen TT, Bresnahan JC, Beattie MS, Jan LY, Jan YN (2015) Regulation of axon regeneration by the RNA repair and splicing pathway. Nat Neurosci 18:817-825. CrossRef Medline

Southwell DG, Froemke RC, Alvarez-Buylla A, Stryker MP, Gandhi SP (2010) Cortical plasticity induced by inhibitory neuron transplantation. Science 327:1145-1148. CrossRef Medline

Sridhar A, Ohlemacher SK, Langer KB, Meyer JS (2016) Robust differentiation of mRNA-reprogrammed human induced pluripotent stem cells toward a retinal lineage. Stem Cells Transl Med 5:417-426. CrossRef Medline

Steward O, Zheng B, Tessier-Lavigne M (2003) False resurrections: distinguishing regenerated from spared axons in the injured central nervous system. J Comp Neurol 459:1-8. CrossRef Medline

Suetterlin P, Drescher U (2014) Target-independent ephrina/EphAmediated axon-axon repulsion as a novel element in retinocollicular mapping. Neuron 84:740-752. CrossRef Medline

Sugitani K, Koriyama Y, Ogai K, Wakasugi K, Kato S (2016) A possible role of neuroglobin in the retina after optic nerve injury: a comparative study of zebrafish and mouse retina. Adv Exp Med Biol 854:671-675. CrossRef Medline

Sun LO, Brady CM, Cahill H, Al-Khindi T, Sakuta H, Dhande OS, Noda M, Huberman AD, Nathans J, Kolodkin AL (2015) Functional assembly of accessory optic system circuitry critical for compensatory eye movements. Neuron 86:971-984. CrossRef Medline

Symonds AC, King CE, Bartlett CA, Sauve Y, Lund RD, Beazley LD, Dunlop SA, Rodger J (2007) EphA5 and ephrin-A2 expression during optic nerve regeneration: a 'two-edged sword.' Eur J Neurosci 25:744-752. CrossRef Medline

Takesian AE, Hensch TK (2013) Balancing plasticity/stability across brain development. Prog Brain Res 207:3-34. CrossRef Medline

Tan L, Zhang KX, Pecot MY, Nagarkar-Jaiswal S, Lee PT, Takemura SY, McEwen JM, Nern A, Xu S, Tadros W, Chen Z, Zinn K, Bellen HJ, Morey M, Zipursky SL (2015) Ig superfamily ligand and receptor pairs expressed in synaptic partners in Drosophila. Cell 163:1756-1769. CrossRef Medline

Tang Y, Stryker MP, Alvarez-Buylla A, Espinosa JS (2014) Cortical plasticity induced by transplantation of embryonic somatostatin or parvalbumin interneurons. Proc Natl Acad Sci U S A 111:18339-18344. CrossRef Medline

Tedeschi A, Dupraz S, Laskowski CJ, Xue J, Ulas T, Beyer M, Schultze JL, Bradke F (2016) The calcium channel subunit $\alpha 2 \beta 2$ suppresses axon regeneration in the adult CNS. Neuron, in press.

Thompson H, Camand O, Barker D, Erskine L (2006) Slit proteins regulate distinct aspects of retinal ganglion cell axon guidance within dorsal and ventral retina. J Neurosci 26:8082-8091. CrossRef Medline

Torrealba F, Guillery RW, Eysel U, Polley EH, Mason CA (1982) Studies of 
retinal representations within the cat's optic tract. J Comp Neurol 211: 377-396. CrossRef Medline

Tuszynski MH, Steward O (2012) Concepts and methods for the study of axonal regeneration in the CNS. Neuron 74:777-791. CrossRef Medline

Ueki Y, Wilken MS, Cox KE, Chipman L, Jorstad N, Sternhagen K, Simic M, Ullom K, Nakafuku M, Reh TA (2015) Transgenic expression of the proneural transcription factor Ascl1 in Muller glia stimulates retinal regeneration in young mice. Proc Natl Acad Sci U S A 112:13717-13722. CrossRef Medline

Vagge A, Nelson LB (2016) Amblyopia update: new treatments. Curr Opin Ophthalmol 27:380-386. CrossRef Medline

Valakh V, Frey E, Babetto E, Walker LJ, DiAntonio A (2015) Cytoskeletal disruption activates the DLK/JNK pathway, which promotes axonal regeneration and mimics a preconditioning injury. Neurobiol Dis 77:1325. CrossRef Medline

Veldman MB, Bemben MA, Thompson RC, Goldman D (2007) Gene expression analysis of zebrafish retinal ganglion cells during optic nerve regeneration identifies KLF6a and KLF7a as important regulators of axon regeneration. Dev Biol 312:596-612. CrossRef Medline

Venugopalan P, Wang Y, Nguyen T, Huang A, Muller KJ, Goldberg JL (2016) Transplanted neurons integrate into adult retinas and respond to light. Nat Commun 7:10472. CrossRef Medline

Vigneswara V, Esmaeili M, Deer L, Berry M, Logan A, Ahmed Z (2015) Eye drop delivery of pigment epithelium-derived factor-34 promotes retinal ganglion cell neuroprotection and axon regeneration. Mol Cell Neurosci 68:212-221. CrossRef Medline

Wada F, Nakata A, Tatsu Y, Ooashi N, Fukuda T, Nabetani T, Kamiguchi H (2016) Myosin Va and endoplasmic reticulum calcium channel complex regulates membrane export during axon guidance. Cell Rep 15:13291344. CrossRef Medline

Wang J, Galvao J, Beach KM, Luo W, Urrutia RA, Goldberg JL, Otteson DC (2016) Novel roles and mechanism for Kruppel-like factor 16 (KLF16) regulation of neurite outgrowth and Ephrin Receptor A5 (EphA5) expression in retinal ganglion cells. J Biol Chem 291:18084-18095. CrossRef Medline

Wang X, Lin J, Arzeno A, Choi JY, Boccio J, Frieden E, Bhargava A, Maynard G, Tsai JC, Strittmatter SM (2015) Intravitreal delivery of human NgR-Fc decoy protein regenerates axons after optic nerve crush and protects ganglion cells in glaucoma models. Invest Ophthalmol Vis Sci 56: 1357-1366. CrossRef Medline

Watkins TA, Wang B, Huntwork-Rodriguez S, Yang J, Jiang Z, EasthamAnderson J, Modrusan Z, Kaminker JS, Tessier-Lavigne M, Lewcock JW (2013) DLK initiates a transcriptional program that couples apoptotic and regenerative responses to axonal injury. Proc Natl Acad Sci U S A 110:4039-4044. CrossRef Medline

Weth F, Fiederling F, Gebhardt C, Bastmeyer M (2014) Chemoaffinity in topographic mapping revisited: is it more about fiber-fiber than fibertarget interactions? Semin Cell Dev Biol 35:126-135. CrossRef Medline

Williams RR, Venkatesh I, Pearse DD, Udvadia AJ, Bunge MB (2015) MASH1/Asclla leads to GAP43 expression and axon regeneration in the adult CNS. PLoS One 10:e0118918. CrossRef Medline

Williams SE, Mann F, Erskine L, Sakurai T, Wei S, Rossi DJ, Gale NW, Holt CE, Mason CA, Henkemeyer M (2003) Ephrin-B2 and EphB1 mediate retinal axon divergence at the optic chiasm. Neuron 39:919-935. CrossRef Medline

Williams SE, Grumet M, Colman DR, Henkemeyer M, Mason CA, Sakurai T (2006) A role for Nr-CAM in the patterning of binocular visual pathways. Neuron 50:535-547. CrossRef Medline

Wilson JR, Friedlander MJ, Sherman SM (1984) Fine structural morphology of identified X-and Y-cells in the cat's lateral geniculate nucleus. Proc R Soc Lond B Biol Sci 221:411-436. CrossRef Medline

Yan B, Vakulenko M, Min SH, Hauswirth WW, Nirenberg S (2016) Maintaining ocular safety with light exposure, focusing on devices for optogenetic stimulation. Vision Res 121:57-71. CrossRef Medline

Yin Y, Cui Q, Li Y, Irwin N, Fischer D, Harvey AR, Benowitz LI (2003) Macrophage-derived factors stimulate optic nerve regeneration. J Neurosci 23:2284-2293. Medline

Yoshimatsu T, D’Orazi FD, Gamlin CR, Suzuki SC, Suli A, Kimelman D, Raible DW, Wong RO (2016) Presynaptic partner selection during retinal circuit reassembly varies with timing of neuronal regeneration in vivo. Nat Commun 7:10590. CrossRef Medline

Yücel YH, Zhang Q, Weinreb RN, Kaufman PL, Gupta N (2003) Effects of retinal ganglion cell loss on magno-, parvo-, koniocellular pathways in the lateral geniculate nucleus and visual cortex in glaucoma. Prog Retin Eye Res 22:465-481. CrossRef Medline

Zhou J, Wen Y, She L, Sui YN, Liu L, Richards LJ, Poo MM (2013) Axon position within the corpus callosum determines contralateral cortical projection. Proc Natl Acad Sci U S A 110:E2714-E2723. CrossRef Medline

Zivraj KH, Tung YC, Piper M, Gumy L, Fawcett JW, Yeo GS, Holt CE (2010) Subcellular profiling reveals distinct and developmentally regulated repertoire of growth cone mRNAs. J Neurosci 30:15464-15478. CrossRef Medline

Zou Y, Stagi M, Wang X, Yigitkanli K, Siegel CS, Nakatsu F, Cafferty WB, Strittmatter SM (2015) Gene-silencing screen for mammalian axon regeneration identifies Inpp5f (Sac2) as an endogenous suppressor of repair after spinal cord injury. J Neurosci 35:10429-10439. CrossRef Medline 